\title{
Mesocellular Silica Foams (MCFs) with Tunable Pore Size as a Support for Lysozyme Immobilization: Adsorption Equilibrium and Kinetics, Biocomposite Properties
}

\author{
Agnieszka Chrzanowska *iD, Anna Derylo-Marczewska and Malgorzata Wasilewska \\ Department of Physical Chemistry, Institute of Chemical Sciences, Faculty of Chemistry, \\ Maria Curie-Sklodowska University in Lublin, M. Curie-Sklodowska Sq. 3, 20-031 Lublin, Poland; \\ annad@hektor.umcs.lublin.pl (A.D.-M.); malgorzata.seczkowska@umcs.pl (M.W.) \\ * Correspondence: agnieszka.chrzanowska@poczta.umcs.lublin.pl
}

Received: 10 July 2020; Accepted: 29 July 2020; Published: 31 July 2020

\begin{abstract}
The effect of the porous structure of mesocellular silica foams (MCFs) on the lysozyme (LYS) adsorption capacity, as well as the rate, was studied to design the effective sorbent for potential applications as the carriers of biomolecules. The structural $\left(\mathrm{N}_{2}\right.$ adsorption/desorption isotherms), textural (SEM, TEM), acid-base (potentiometric titration), adsorption properties, and thermal characteristics of the obtained lysozyme/silica composites were studied. The protein adsorption equilibrium and kinetics showed significant dependence on silica pore size. For instance, LYS adsorption uptake on MCF-6.4 support (pore diameter $6.4 \mathrm{~nm}$ ) was about $0.29 \mathrm{~g} / \mathrm{g}$. The equilibrium loading amount of LYS on MCF-14.5 material (pore size $14.5 \mathrm{~nm}$ ) increased to $0.55 \mathrm{~g} / \mathrm{g}$. However, when the pore diameter was larger than $14.5 \mathrm{~nm}$, the LYS adsorption value systematically decreased with increasing pore size (e.g., for MCF- 30.1 was only $0.27 \mathrm{~g} / \mathrm{g}$ ). The electrostatic attractive interactions between the positively charged lysozyme (at $\mathrm{pH}=7.4$ ) and the negatively charged silica played a significant role in the immobilization process. The differences in protein adsorption and surface morphology for the biocomposites of various pore sizes were found. The thermal behavior of the studied bio/systems was conducted by TG/DSC/FTIR/MS coupled method. It was found that the thermal degradation of lysozyme/silica composites was a double-stage process in the temperature range $165-420-830^{\circ} \mathrm{C}$.
\end{abstract}

Keywords: mesocellular silica foams; adsorption equilibrium; adsorption kinetics; protein/silica biocomposites; microscopic analysis; thermal analysis

\section{Introduction}

The biomolecules adsorption (i.e., proteins, enzymes, pharmaceuticals) on liquid/solid interfaces is a common and complex phenomenon, important in its prominent role in biology, medicine, biotechnology, and food processing applications. Therefore, it is very important to fully understand mechanisms of adsorption processes of the compounds showing biological activity at different interface boundaries, as well as their practical and potential application as modified biological materials (BioSS-Biological Surface Science) [1,2].

The adsorption capacity and selectivity depend on several factors, including the protein properties (size, shape, charge, structure, stability, isoelectric point, and unfolding rate), the process conditions (solution $\mathrm{pH}$, ionic strength, temperature), and especially the physicochemical properties of materials (surface porosity, morphology, hydrophobicity, heterogeneity, electric charge) [3-7]. For the large biological molecules immobilized on a porous support, the selection of optimal adsorbent is of great 
importance. In the case of mesoporous materials with pore sizes comparable with the biomolecule diameter, the internal loading of biomolecules should be lower due to the sieving effects. For materials with a pore diameter greater than the size of the adsorbed molecules, a possibility of penetration of biomolecules into mesopores and stronger interactions in the confined space results in higher adsorption. There is some evidence in the literature that the adsorbent pore diameter, which is at least two times larger than the adsorbate molecular diameter, enables full access to the internal space of mesoporous materials $[8,9]$. Thus, many efforts were undertaken to tune the mesopore size and structure of the well-ordered mesoporous molecular sieves (MMSes) and mesoporous silica nanoparticles (MSNs) to promote their bioapplications in catalysis, separation, disease diagnostics or as biosensors [10-15]. Many reports focused on usage of the most popular MMSes (MCM-41, SBA-15, MCM-48, MCM-21, MSE, FSM) as the efficient supports for the immobilization of various enzymes (cytochrome C, lysozyme, bovine serum albumin, ovalbumin, myoglobin, hemoglobin, trypsin, lipase, chloroperoxidase), to find the optimal size relation between mesopores and molecular dimensions of biomolecules for better control of adsorption process [16-25].

Among several types of high ordered mesoporous silica materials available for macromolecules immobilization, mesocellular silica foam (MCF) is one of the most suitable adsorbents for protein adsorption and separation, because of its unique structural properties (high surface area $~ 500-1000 \mathrm{~m}^{2} / \mathrm{g}$, large pore volume $\sim 2 \mathrm{~cm}^{3} / \mathrm{g}$, large pore size up to $50 \mathrm{~nm}$, uniformity of pore structure, high adsorption capacity, and especially the possibility of precise adjusting the structure and particle morphology). There are only a few reports regarding adsorption of myoglobin, lysozyme (LYS), bovine serum albumin (BSA), ovalbumin (OVA), chloroperoxidase, trypsin, a-amylase, glucoamylase on the MCF silica support [26]. For example, Russo et al. [27] studied the influence of surface functionalization on the adsorption capacity of BSA and LYS on the MCF silica with $31.5 \mathrm{~nm}$ pores. Essa et al. [28] found that adsorption of myoglobin on MMSes with differential porosities is relatively high for the MCF silica (pore size $14 \mathrm{~nm}$ ) and SBA-15 (pore size $6.2 \mathrm{~nm}$ ) in comparison to other silicas (MCM-41 pore size $3.1 \mathrm{~nm}$, MSE pore size $6.0 \mathrm{~nm}$, CNS pore size $14.7 \mathrm{~nm}$ ). Han et al. [29] studied that the catalytic activity of chloroperoxidase enzyme on MCF (pore size $15 \mathrm{~nm}$ ) and observed that it is higher than on MCM-48 (pore size $3.2 \mathrm{~nm}$ ) and SBA-15 (pore size $4.2 \mathrm{~nm}$ and $7.0 \mathrm{~nm}$ ). In our previous work, we found that MCF material with larger pores (pore size $10 \mathrm{~nm}$ and $16 \mathrm{~nm}$ ) shows higher adsorption uptakes towards BSA and OVA proteins which can penetrate its internal structure to a larger extent [30]. However, there is still a lack of deeper analysis of the pore size - adsorption value relations in a wider range of pore diameters.

In the paper, the wide analysis of the dependence between the MCF pore size and specific surface area, and lysozyme adsorption capacity and rate is presented to optimize the adsorbent structural characteristics with regard to adsorbate uptake and density. It was found that there is an optimum relation between pore diameter and protein size in order to attain the maximum adsorption or surface density with regard to possible applications. Thus, the studies are important to obtain the material with desired porosity, which can be used as the effective support for biomolecules. We aim at the analysis of the influence of MCF pore size in a wider range of pore diameters on the adsorption capacity and rate of lysozyme, which is a comparatively small protein enzyme. A lysozyme from chicken egg white (LYS) was chosen as a model protein enzyme for immobilization on MCF supports due to its physicochemical properties and biological function: high structural stability (due to four disulfide bridges (S-S) and inflexibility between $\mathrm{pH}=1.5$ and 12; it makes lysozyme a fine model protein for interfacial adsorption in a wide range of $\mathrm{pH}$ ); "hard model protein" which can undergo interfacial reorientations but does not unfold at an interface; small globular protein of molecular mass $14.3 \mathrm{kDa}$ and hydrodynamic radius $\sim 2 \mathrm{~nm}$ (LYS molecules adsorbed on the surface and inside MCF pores); positively charged at $\mathrm{pH}=7.4$ (electrostatic attraction between the protein and the silica material); strong antibacterial activity against Gram-positive organism, anti-inflammatory, immune-modulatory, and anti-tumor properties. 
Several samples of MCF materials with tunable porosity and pore size were synthesized as carriers for immobilizing LYS molecules. The adsorption processes of lysozyme from phosphate-buffered saline (PBS) solutions in physiological conditions ( $\mathrm{pH}=7.4$ ) on the series of MCF materials with different porosity were investigated. The equilibrium adsorption isotherms and kinetic dependences (concentration vs. time profiles) for the adsorption processes of biomolecules were determined. The dependences between pore diameter and kinetic rate were analysed. The acid-base character and surface charge density of the MCF supports covered by protein molecules were determined by using the potentiometric titration. Likewise, the structural, morphological, and textural properties of protein/silica composites were characterized employing the nitrogen adsorption/desorption isotherms, the Scanning Electron Microscopy (SEM), and Transmission Electron Microscopy (TEM). Additionally, the thermal stability and characteristics of the decomposition products of lysozyme/silica were studied by using a combination of the Thermogravimetric Analyzer (TG) with Mass Spectrometer (MS) or a Fourier Transform Infrared Spectrometer (FTIR). The applied powerful methods (TG/FTIR/MS) provided comprehensive information for understanding enzyme protein immobilization on the silica support.

\section{Results and Discussion}

\subsection{Structure Characterization of MCF Supports}

The porosity of the synthesized series of siliceous mesocellular foams (MCFs) was investigated by the nitrogen adsorption/desorption method. The comparison of nitrogen adsorption/desorption isotherms for three selected mesoporous MCF materials: MCF-6.4 with small pore size $\left(D_{h}=6.4 \mathrm{~nm}\right.$, the average hydraulic pore diameter), MCF-14.5 with medium pore size $\left(D_{h}=14.5 \mathrm{~nm}\right)$, MCF-30.1 with large pore size $\left(D_{h}=30.1 \mathrm{~nm}\right)$ is presented in Figure S1A (Supplementary Material). The isotherms for the studied MCF adsorbents correspond to IV type according to IUPAC classification. They reveal well-defined $\mathrm{H} 1$ hysteresis loops with very steep and parallel adsorption and desorption branches at higher relative pressures [31,32]. The maximum adsorption is the smallest for MCF-6.4 material; however, it is comparable for MCF-14.5, and MCF-30.1 supports what is associated with similar large total pore and mesopore volumes of these materials. Moreover, the shift of hysteresis loops towards higher relative pressures for MCF-14.5 and MCF-30.1 carriers in comparison to MCF-6.4 is associated with larger pore diameters.

The parameters characterizing the textural properties of all synthesized MCF supports are compared in Table 1. It should be noted that the obtained MCF materials are characterized by a differentiated mesoporous structure concerning the values of specific surface areas, pore volumes, and pore diameters. All MCF materials show a well-developed porous structure with a high BET (Brunauer-Emmett-Teller) surface area varying from 250 to $720 \mathrm{~m}^{2} / \mathrm{g}$, total pore volume $1-2 \mathrm{~cm}^{3} / \mathrm{g}$, and a hydraulic pore diameter in the range $6-30 \mathrm{~nm}$. As can be seen, the average pore diameters obtained from adsorption and desorption branches of isotherms using the Barrett-Joyner-Halenda (BJH) procedure are 6-38 nm and 5-30 nm, respectively. It is worthy to note that the pore sizes of synthesized MCF adsorbents are larger than the size of the lysozyme molecule (the hydrodynamic diameter $\sim 4 \mathrm{~nm})$. The specific surface area of MCF- $6.4\left(716 \mathrm{~m}^{2} / \mathrm{g}\right)$ is by ca. 3 times higher than for MCF-30.1 material. No micropores are detected for MCF-6.4, however, in the case of the other materials slight micropores are found which confirm the high quality of the obtained adsorbents with uniform porosity.

Pore size distributions (PSDs) for three selected materials calculated from the adsorption and desorption data using the BJH method are demonstrated in Figure S1B,C (Supplementary Material). The PSD plots for MCF-6.4 and MCF-14.5 show sharp peaks, suggesting that porous structure is fairly homogeneous with narrow pore sizes, however, for MCF-30.1 the pore size distribution is wider. The PSDs calculated from the adsorption and desorption data are shifted towards higher values of pore diameter as follows MCF-6.4 < MCF-14.5 < MCF-30.1. 
Table 1. Textural parameters of the obtained mesoporous silica materials.

\begin{tabular}{|c|c|c|c|c|c|c|c|c|c|}
\hline \multirow{3}{*}{ Material } & \multirow{2}{*}{\multicolumn{2}{|c|}{$\begin{array}{c}\text { Surface Area } \\
{\left[\mathrm{m}^{2} / \mathrm{g}\right]}\end{array}$}} & \multirow{2}{*}{\multicolumn{2}{|c|}{$\begin{array}{l}\text { Pore Volume } \\
\qquad\left[\mathrm{cm}^{3} / \mathrm{g}\right]\end{array}$}} & \multicolumn{2}{|c|}{$\begin{array}{c}\text { Pore Diameter by BJH } \\
\text { Adsorption }\end{array}$} & \multicolumn{2}{|c|}{$\begin{array}{c}\text { Pore Diameter by BJH } \\
\text { Desorption }\end{array}$} & \multirow{2}{*}{$\begin{array}{c}\text { Pore Size } \\
\text { (Average } \\
\text { Hydraulic) } \\
\text { [nm] }\end{array}$} \\
\hline & & & & & $\begin{array}{c}\text { PSD } \\
\text { Average } \\
\text { [nm] }\end{array}$ & $\begin{array}{l}\text { Mode } \\
{[\mathrm{nm}]}\end{array}$ & $\begin{array}{c}\text { PSD } \\
\text { Average } \\
\text { [nm] }\end{array}$ & $\begin{array}{l}\text { Mode } \\
{[\mathrm{nm}]}\end{array}$ & \\
\hline & a $S_{B E T}$ & ${ }^{\mathrm{b}} S_{\text {ext }}$ & ${ }^{\mathrm{c}} V_{t}$ & ${ }^{\mathrm{d}} V_{m e s}$ & ${ }^{\mathrm{e}} D_{a v, a d s}$ & ${ }^{\mathrm{f}} D_{m o, a d s .}$ & ${ }^{\mathrm{g}} D_{a v, d e s .}$ & ${ }^{\mathrm{h}} D_{m o, d e s}$ & ${ }^{\mathrm{i}} D_{h}$ \\
\hline MCF-6.4 & 716 & 29 & 1.15 & 1.09 & 5.8 & 6.6 & 5.2 & 4.9 & 6.4 \\
\hline MCF-7.4 & 685 & 38 & 1.26 & 1.18 & 7.2 & 7.9 & 6.5 & 6.4 & 7.4 \\
\hline MCF-8.7 & 522 & 63 & 1.14 & 1.03 & 8.3 & 8.9 & 7.4 & 8.3 & 8.7 \\
\hline MCF-10.1 & 533 & 72 & 1.32 & 1.19 & 9.9 & 10.1 & 8.8 & 9.3 & 10.1 \\
\hline MCF-12.4 & 569 & 65 & 1.76 & 1.63 & 13.4 & 13.7 & 11.9 & 10.8 & 12.4 \\
\hline MCF-14.5 & 547 & 135 & 1.98 & 1.74 & 16.5 & 16.6 & 13.6 & 12.6 & 14.5 \\
\hline MCF-15.5 & 494 & 262 & 1.91 & 1.44 & 20.1 & 17.0 & 16.9 & 17.9 & 15.5 \\
\hline MCF-20.3 & 435 & 41 & 2.21 & 2.00 & 25.2 & 27.7 & 20.6 & 22.2 & 20.3 \\
\hline MCF-25.8 & 301 & 231 & 1.94 & 1.45 & 32.3 & 27.9 & 23.3 & 21.8 & 25.8 \\
\hline MCF-27.7 & 267 & 67 & 1.85 & 1.73 & 34.5 & 38.0 & 26.8 & 29.6 & 27.7 \\
\hline MCF-30.1 & 250 & 61 & 1.88 & 1.76 & 37.5 & 38.7 & 30.2 & 30.9 & 30.1 \\
\hline
\end{tabular}

${ }^{a} S_{B E T}$, BET specific surface area; ${ }^{b} S_{\text {ext }}$, external surface area; ${ }^{c} V_{t}$, total pore volume; ${ }^{d} V_{\text {mes }}$, mesopore volume; e,g $\mathrm{D}_{a v}$,ads.des., $\mathrm{BJH}$ average pore diameters for cylinder pores geometry from adsorption and desorption branch of isotherms; ${ }^{\mathrm{f}, \mathrm{h}} \mathrm{D}_{m o, a d s .,}$ des., pore diameters from the PSD maxima by BJH (mode) obtained from adsorption/desorption isotherms for cylinder pores geometry; ${ }^{i} \mathrm{D}_{h}$, average hydraulic pore diameter.

\subsection{Adsorption Equilibrium and Kinetics}

In Figure 1A the adsorption isotherms of lysozyme are compared for all synthesized MCF supports. Moreover, in Figure 1B the experimental isotherms are compared for three selected materials with the medium, small, and large pore sizes. One can find that the strongest adsorption is observed for MCF-14.5. In the case of other materials of lower and higher pore sizes, a decrease of LYS adsorption is found. Moreover, the lowest adsorption is observed for MCF-6.4 and MCF-30.1, the supports with the narrowest and the most widened pores. This tendency is well presented in Figure 1C. Such a behavior may be correlated with the values of specific surface areas and pore sizes of investigated adsorbents. It is evident that the optimum pore size for lysozyme adsorption is around $14.5 \mathrm{~nm}$. The other MCF materials with comparable specific surface areas, however, with different pore sizes (lower and higher than $14.5 \mathrm{~nm}$ ) reveal weaker adsorption affinity. It may be explained by the relation of protein size and pore diameter, which in the case of MCF-14.5 and LYS is responsible for the increase of the adsorption forces. However, when we regard the adsorption surface density (adsorption/specific surface area) it occurs that the density maximum is shifted to MCF-25.8 (see Figure 1D). Thus, in the case of this material, the protein layer of the highest density is formed. We can compare our adsorption results with those obtained by other authors for the silica materials with pore sizes in the range of 3.9-19.2 nm. The lysozyme adsorption isotherms on SBA-15 with different pore sizes (9.8-19.2 nm) at $\mathrm{pH}=10.6$ have been reported by Santos et al. [33] the adsorbed amounts were equal to $0.2 \mathrm{~g} / \mathrm{g}$ (pore size $9.8 \mathrm{~nm}$ ), $0.28(11.7 \mathrm{~nm}), 0.47(17.3 \mathrm{~nm})$ and $0.79(19.2 \mathrm{~nm})$. In another study, MCM-41 (pore size $3.9 \mathrm{~nm}$ ) and SBA-15 $(8.8 \mathrm{~nm})$ were used and LYS adsorption capacity was estimated to be 0.19 and 0.38 , and 0.41 and $0.48 \mathrm{~g} / \mathrm{g}$ at $\mathrm{pH}=6$ and 10.5, respectively [34]. According to Moerz et al. [35], the amount of LYS adsorbed on SBA-15 (pore size $6.6 \mathrm{~nm}$ ) at $\mathrm{pH}=6$ and 10.6 was: $\sim 0.12 \mathrm{~g} / \mathrm{g}(\sim 8.5 \mu \mathrm{mol} / \mathrm{g})$ and $\sim 0.29$ $(\sim 20.5 \mu \mathrm{mol} / \mathrm{g})$, respectively; however, at $\mathrm{pH} \sim 7.3$, it was about 1.5 times lower $(\sim 13.5 \mu \mathrm{mol} / \mathrm{g} ; \sim 0.19 \mathrm{~g} / \mathrm{g})$ than in the case of our material. The adsorption capacities characterizing our MCF materials are as follows (pH = 7.4): $0.29 \mathrm{~g} / \mathrm{g}$ (pore size $6.4 \mathrm{~nm}), 0.42(10.1 \mathrm{~nm}), 0.49(12.4 \mathrm{~nm}), 0.55(14.5 \mathrm{~nm}), 0.49$ $(20.3 \mathrm{~nm})$. Considering the dependence of protein adsorption on solution $\mathrm{pH}$ and ionic strength we can state that our materials reveal good sorption properties. 

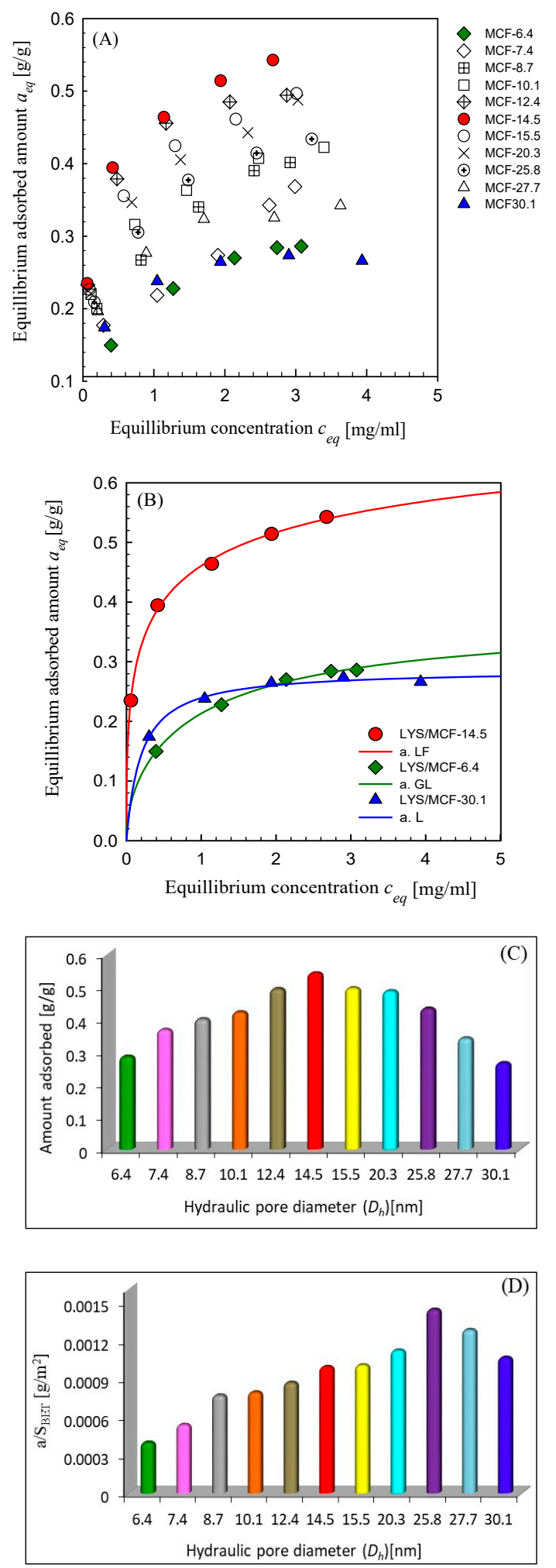

Figure 1. (A) Comparison of lysozyme (LYS) adsorption isotherms on mesoporous silica materials with different pore diameters; (B) LYS adsorption isotherms on three selected mesocellular silica foams (MCF) silica materials. Solid lines correspond to the fitted Generalized-Langmuir (GL) isotherm; (C) Relationships between the LYS adsorbed amounts, and (D) the LYS adsorption density versus the hydraulic pore diameter. Adsorption conditions: the initial concentration of protein solution $\left(\mathrm{c}_{0}=5 \mathrm{mg} / \mathrm{mL}\right)$ in phosphate-buffered saline $(\mathrm{pH}=7.4)$ at $25^{\circ} \mathrm{C}$. 
For the analysis of these data, the Generalized Langmuir equation was used. As one can find the GL isotherm well fitted the experimental data. The parameters of this equation (and its special forms) are presented in Table 2. One can find that the optimized values of adsorption capacities $\left(a_{m}\right)$ agree quite well with the experimental uptakes, the observed small differences (lower theoretical $a_{m}$ values in comparison to experimental ones) result from the fact that the experimental systems did not yet reach equilibrium. For two systems LYS/MCF-14.5 and LYS/MCF-6.4, the values of heterogeneity parameters $m$ and $n$ lower than 1 indicate their high nonhomogeneity. However, for LYS/MCM-30.1 energetic homogeneity is observed $(m, n=1)$, which may be correlated with the largest pores of adsorbent and resulting in a more homogeneous distribution of protein molecules on the surface.

Table 2. Parameters of the Generalized Langmuir (GL) isotherm equation (optimized to (LF) Langmuir-Freundlich or (L) Langmuir Isotherms) characterizing the adsorption systems investigated.

\begin{tabular}{cccccccc}
\hline Adsorption System & Fitted Isotherm & $\boldsymbol{a}_{\boldsymbol{m}}$ & $\boldsymbol{m}$ & $\boldsymbol{n}$ & $\log \boldsymbol{K}$ & $\boldsymbol{R}^{\mathbf{2}}$ & $\mathrm{SD}(\boldsymbol{a})$ \\
\hline LYS/MCF-14.5 & LF & 0.82 & 0.40 & 0.40 & 0.25 & 0.997 & 0.008 \\
LYS/MCF-6.4 & GL & 0.37 & 0.50 & 1 & -0.32 & 0.997 & 0.004 \\
LYS/MCF-30.1 & L & 0.29 & 1 & 1 & 0.71 & 0.985 & 0.006 \\
\hline
\end{tabular}

$a_{m}$, adsorption capacity; $m, n$, heterogeneity parameters describing the shape (asymmetry) of adsorption energy distribution function; $K$, equilibrium constant related to characteristic adsorption energy; $R_{2}$, determination coefficients; SD, standard deviations.

In Figure 2, the experimental concentration and adsorption profiles are compared for the selected MCF supports. The concentration vs. time curves was analyzed by using the multi-exponential (m-exp) equation (theoretical lines in Figure 2A) (the parameters of this equation are presented in Table 3), and the other kinetic equations and models (first-order (FOE), second-order (SOE), mixed-order (MOE), fractal first-order (f-FOE), fractal second-order (f-SOE), fractal mixed-order (f-MOE) equation, intraparticle diffusion model (IDM), McKay pore diffusion model (PDM)). The choice of m-exp equation for the description of experimental data was based on the lowest values of standard deviation SD. The optimization results for m-exp equation to other equations and models are compared in Table S1 (Supplementary Material) in which the values of relative standard deviations $\mathrm{SD}\left(\mathrm{c} / \mathrm{c}_{0}\right)$ are given. Basing on the average SD values one can find that m-exp equation gives the best optimization results, for the PDM model the poorest results were found. However, it should be stated that in the case of the system LYS/MCM-6.4 the lowest SD values were found for two fractal models f-FOE and f-SOE (SD $=0.246 \%$ and $0.247 \%$, respectively), but for m-exp equation SD is only slightly higher ( $\mathrm{SD}=0.337 \%$ ).

Table 3. Optimized parameters of m-exp eq.

\begin{tabular}{|c|c|c|c|c|c|c|}
\hline System & $\begin{array}{c}f_{1}, \\
\log k_{1}\end{array}$ & $\begin{array}{c}f_{2} \\
\log k_{2}\end{array}$ & $\begin{array}{c}f_{3} \\
\log k_{3}\end{array}$ & $\begin{array}{c}t_{1 / 2} \\
{[\mathrm{~min}]}\end{array}$ & $\begin{array}{c}\mathrm{SD}(\mathrm{c}) / \mathrm{c}_{\mathrm{o}} \\
{[\%]}\end{array}$ & $1-R^{2}$ \\
\hline LYS/MCF-6.4 & $\begin{array}{l}0.054 \\
-2.24\end{array}$ & $\begin{array}{l}0.946 \\
-3.91\end{array}$ & 0 & 358.7 & 0.337 & 0.0037 \\
\hline LYS/MCF-14.5 & $\begin{array}{c}0.231 \\
0.21\end{array}$ & $\begin{array}{l}0.125 \\
-2.48\end{array}$ & $\begin{array}{l}0.644 \\
-9.99\end{array}$ & 1.7 & 0.414 & 0.0027 \\
\hline LYS/MCF-30.1 & $\begin{array}{c}0.187 \\
0.55\end{array}$ & $\begin{array}{l}0.813 \\
-4.02\end{array}$ & 0 & 0.5 & 0.723 & 0.021 \\
\hline
\end{tabular}

$f_{i}(i=1,2, \ldots, n)$, coefficients determining a fraction of adsorbate adsorbed with the rate constant $k_{i} ; \log k_{i}$, rate constant logarithms; $t_{1 / 2}$, adsorption half-time; $\mathrm{SD}\left(\mathrm{c} / \mathrm{c}_{\mathrm{o}}\right)$, standard deviation; $1-\mathrm{R}^{2}$, indetermination coefficient.

In Table 3, the values of optimized m-exp eq. parameters characterizing adsorption kinetics are compared: the rate constant $\log$ arithms $\left(\log k_{i}\right)$ and the $f_{i}$ coefficients determining a fraction of a solute adsorbed with rate $k_{i}$, moreover, the adsorption half-time is presented. The quality of optimization results is confirmed by low standard deviation, SD, values $(0.337-0.723 \%)$, and indetermination coefficient, $1-R^{2}(0.0027-0.021)$. The kinetic experimental systems are well optimized by 2 or 3 terms of m-exp equation. The values of $\log k_{i}$ and $f_{i}$ parameters characterizing the stages of the adsorption 
process indicate that the initial stage is quicker for all systems investigated. It may be attributed to adsorption on the external surfaces which are accompanied by the second slower stage connected with adsorption in the pore system. Analyzing the experimental kinetic curves one can find that the adsorption process is the slowest for MCF-6.4 $\left(t_{1 / 2}=358.7\right)$ with the narrowest pores which indicates some problems with the diffusion of protein molecules into the internal pore space. The range near adsorption equilibrium was attained in the shortest period for MCF-30.1 $\left(t_{1 / 2}=0.5\right)$ which may be explained by easier diffusion of protein molecules into large pores. The adsorption process is slightly slower for MCF-14.5 ( $\left.t_{1 / 2}=1.7\right)$ which means that the pore sizes of this material do not disturb protein diffusion. Moreover, the kinetic profiles for MCF-30.1 and MCF-6.4 achieve the comparable close to equilibrium adsorption values, however, for MCF-14.5 the equilibrium adsorption is higher, and these results are in accordance with batch experiment (Figure 2B).
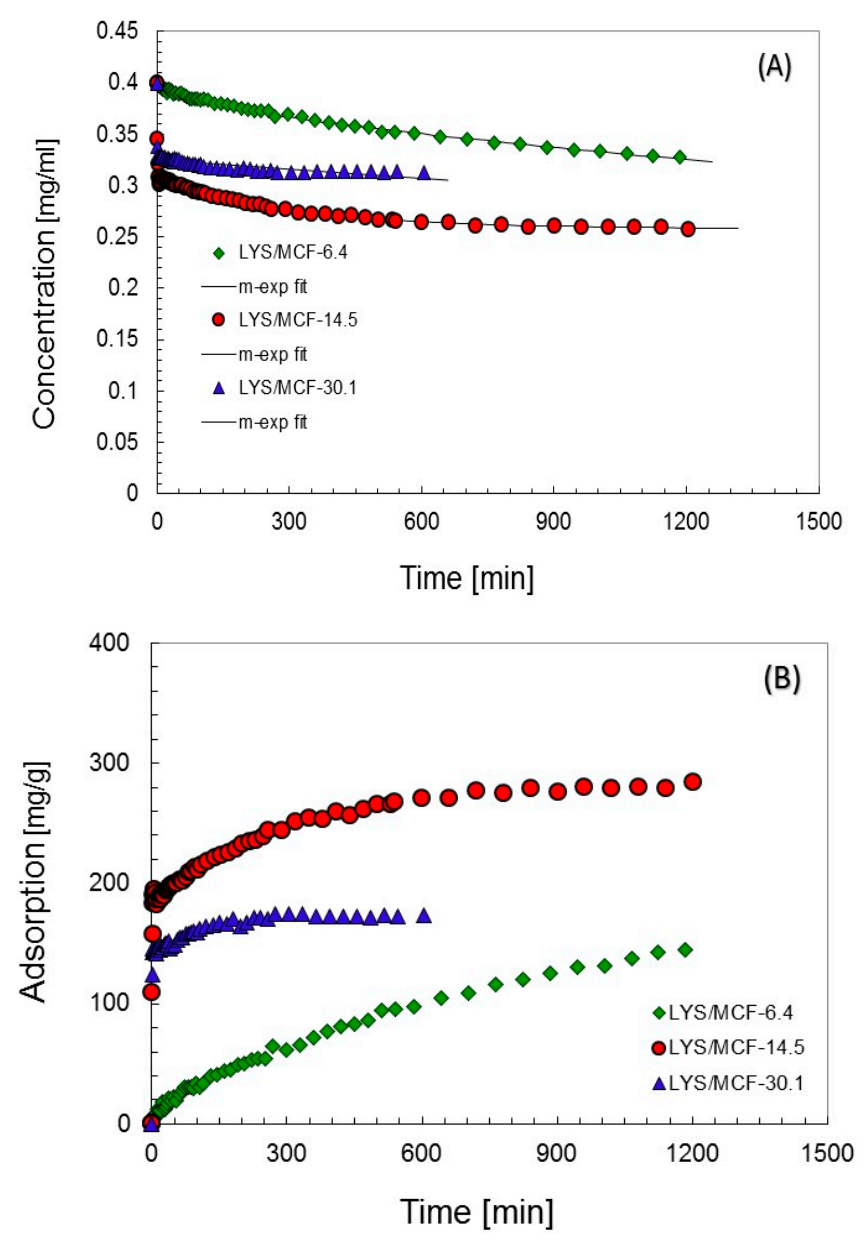

Figure 2. The comparison of concentration (A) and adsorption (B) profiles measured for lysozyme adsorption on MCF-14.5, MCF-6.4, and MCF-30.1 supports. Adsorption conditions: $\mathrm{c}_{0}=0.4 \mathrm{mg} / \mathrm{mL}$, $\mathrm{T}=25^{\circ} \mathrm{C} ; \mathrm{pH}=7.4$.

\subsection{Physicochemical Properties of Protein/MCF Composites}

\subsubsection{Structural Analysis}

The $\mathrm{N}_{2}$ adsorption/desorption measurements were used to determine semi-qualitatively whether the adsorbed biomolecules were situated inside the pores of the MCF materials and/or at the external surface. The nitrogen adsorption/desorption isotherms for pure supports (MCF-6.4, MCF-14.5, MCF-30.1) and biocomposites are compared in Figure S2A (Supplementary Material). The parameters characterizing the changes in the pore structure of MCF materials after protein adsorption are 
summarized in Table 4. It can be found in Figure S2A (Supplementary Material) that the amount of nitrogen adsorbed on biocomposite is decreased with the increasing amount of LYS (the LYS adsorbed amounts from solution are as follows: for MCF-6.4 (pore size $6.4 \mathrm{~nm}$ ) is ca. $0.29 \mathrm{~g} / \mathrm{g}$, for MCF-14.5 (pore size $14.5 \mathrm{~nm}$ ) increased to $0.55 \mathrm{~g} / \mathrm{g}$, for MCF-30.1 (pore size $30.1 \mathrm{~nm}$ ) is ca. $0.27 \mathrm{~g} / \mathrm{g}$.

Table 4. Pore structure parameters of the investigated pure supports and biocomposites calculated from $\mathrm{N}_{2}$ adsorption/desorption isotherms. Adsorption conditions: $c_{0}=5 \mathrm{mg} / \mathrm{mL} ; t_{a d s}=24 \mathrm{~h} ; \mathrm{T}=25^{\circ} \mathrm{C}$; $\mathrm{pH}=7.4$.

\begin{tabular}{|c|c|c|c|c|c|c|c|c|c|}
\hline \multirow{3}{*}{ Material } & \multirow{2}{*}{\multicolumn{2}{|c|}{$\begin{array}{l}\text { Surface Area } \\
{\left[\mathrm{m}^{2} / \mathrm{g}\right]}\end{array}$}} & \multirow{2}{*}{\multicolumn{2}{|c|}{$\begin{array}{l}\text { Pore Volume } \\
\qquad\left[\mathrm{cm}^{3} / \mathrm{g}\right]\end{array}$}} & \multicolumn{2}{|c|}{$\begin{array}{c}\text { Pore Diameter by BJH } \\
\text { Adsorption }\end{array}$} & \multicolumn{2}{|c|}{$\begin{array}{l}\text { Pore Diameter by } \\
\text { BJH Desorption }\end{array}$} & \multirow{2}{*}{$\begin{array}{c}\text { Pore Size } \\
\text { (Average } \\
\text { Hydraulic) } \\
\text { [nm] }\end{array}$} \\
\hline & & & & & $\begin{array}{c}\text { PSD } \\
\text { Average } \\
\text { [nm] }\end{array}$ & $\begin{array}{c}\text { Mode } \\
{[\mathrm{nm}]}\end{array}$ & $\begin{array}{c}\text { PSD } \\
\text { Average } \\
\text { [nm] }\end{array}$ & $\begin{array}{c}\text { Mode } \\
{[\mathrm{nm}]}\end{array}$ & \\
\hline & ${ }^{\text {a }} S_{B E T}$ & ${ }^{\mathrm{b}} S_{\text {ext }}$ & ${ }^{\mathrm{c}} V_{t}$ & ${ }^{\mathrm{d}} V_{m e s}$ & ${ }^{\mathrm{e}} D_{a v, a d s}$ & ${ }^{\mathrm{f}} D_{\text {mo, ads. }}$ & ${ }^{\mathrm{g}} D_{a v, \text { des. }}$ & ${ }^{\mathrm{h}} D_{m o, \text { des. }}$ & ${ }^{\mathrm{i}} D_{h}$ \\
\hline MCF-6.4 & 716 & 29 & 1.15 & 1.09 & 5.8 & 6.6 & 5.2 & 4.9 & 6.4 \\
\hline MCF-14.5 & 547 & 135 & 1.98 & 1.74 & 16.5 & 16.6 & 13.6 & 12.6 & 14.5 \\
\hline MCF-30.1 & 250 & 61 & 1.88 & 1.76 & 37.5 & 38.7 & 30.2 & 30.9 & 30.1 \\
\hline LYS/MCF-6.4 & 346 & 7 & 0.49 & 0.48 & 5.2 & 6.3 & 4.7 & 5.5 & 5.7 \\
\hline LYS/MCF-14.5 & 38 & 22 & 0.12 & 0.08 & 12.5 & 12.2 & 10.9 & 10.7 & 12.6 \\
\hline LYS/MCF-30.1 & 114 & 25 & 0.50 & 0.44 & 18.5 & 20.7 & 14.9 & 17.6 & 17.5 \\
\hline
\end{tabular}

${ }^{a} S_{B E T}, B E T$ specific surface area; ${ }^{b} S_{\text {ext }}$, external surface area; ${ }^{c} V_{t}$, total pore volume; ${ }^{d} V_{\text {mes }}$, mesopore volume; e,g $\mathrm{D}_{a v, a d s ., d e s .,} \mathrm{BJH}$ average pore diameters for cylinder pores geometry from adsorption and desorption branch of isotherms; ${ }^{\mathrm{f}} \mathrm{h} \mathrm{D}_{\text {mo,ads.,des., }}$ pore diameters from the PSD maxima by BJH (mode) obtained from adsorption/desorption isotherms for cylinder pores geometry; ${ }^{i} \mathrm{D}_{h}$, average hydraulic pore diameter.

Furthermore, the analysis of structural properties (Table 4) of the MCF silica supports before and after LYS adsorption shows that the porosity parameters $\left(S_{B E T}\right.$, the BET specific surface area; $V_{t}$, the total pore volume; $V_{\text {mes }}$, the mesopore volume; $D_{h y}$, the average hydraulic pore diameter) estimated from $\mathrm{N}_{2}$ adsorption/desorption data are strongly reduced. The strongest reduction of pore characteristics is observed for LYS/MCF-14.5 biocomposite which is very well correlated with the highest adsorption of protein. It can be seen that for MCF-14.5 material with immobilized LYS the BET surface area decreased from $547 \mathrm{~m}^{2} / \mathrm{g}$ to $38 \mathrm{~m}^{2} / \mathrm{g}(93 \%)$. On the other hand, for LYS/MCF-6.4 and LYS/MCF-30.1 $S_{B E T}$ values diminished by approximately $52 \%$ and $54 \%$, respectively. Additionally, LYS adsorption leads to decrease of the total pore volume of approximately: $94 \%$ for MCF-14.5, 57\% for MCF-6.4, and 73\% for LYS/MCF-30.1. The values of average pore diameter $\left(D_{a v}\right)$ and the mean hydraulic pore diameter $\left(D_{h y}\right)$ also decrease after protein adsorption. The reduction in the specific surface area, pore volume, and size after LYS adsorption observed for all MCF materials indicates that the protein molecules are adsorbed inside the mesopores of MCF material as well as on the external surfaces. The evolution of pore-size distribution functions obtained from BJH model for isotherm desorption branches for MCF-14.5, MCF-6.4, and MCF-30.1 after protein adsorption are presented in Figure S2B (Supplementary Material). One can find a strong decrease of the peak heights for all biocomposites in comparison to pure supports: $96 \%$ for MCF-14.5, 26\% for MCF-6.4, 61\% for MCF-30.1.

\subsubsection{Acid-Base Properties}

To evaluate the acid-base character, surface charge, and nature of the interactions between lysozyme and porous MCF the potentiometric titration measurements were applied. The surface charge density $\left(Q_{s}\right)$ curves as a function of $\mathrm{pH}$ calculated from the experimental data for the pure MCF materials and LYS/MCF systems are illustrated in Figure 3A,B. 

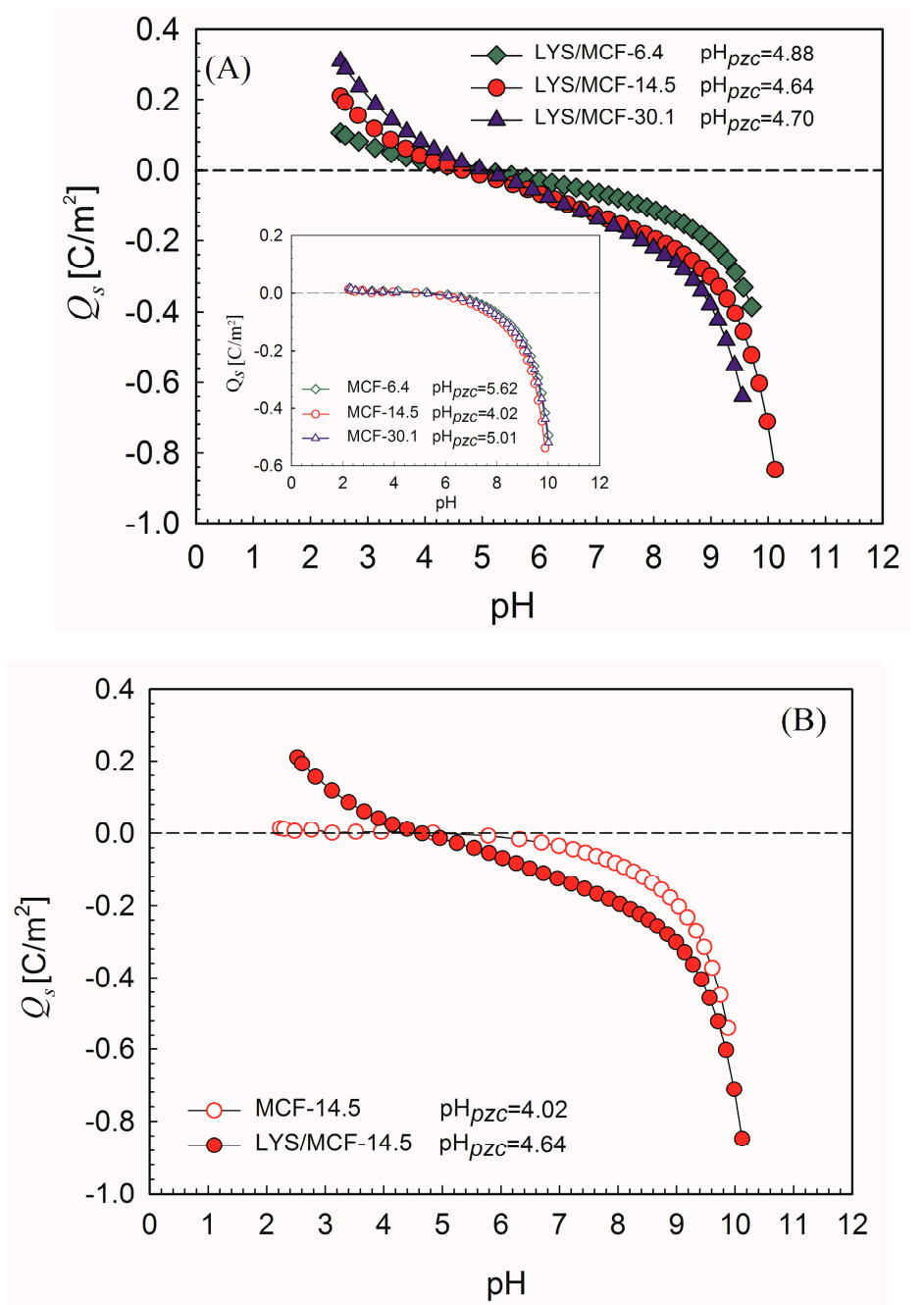

Figure 3. (A) Dependence of surface charge density, $Q_{s}$, on $\mathrm{pH}$ for MCF-6.4, MCF-14.5, MCF-30.1 materials with immobilized lysozyme. Inset: dependence of $Q_{\mathrm{s}} \mathrm{vs}$. $\mathrm{pH}$ for pure MCF-6.4, MCF-14.5, MCF-30.1 silicas; (B) Surface charge density, $Q_{s}$, for MCF-14.5 before and after LYS adsorption. The measurements were carried out by potentiometric titration for ionic strength $\mathrm{I}=0.1 \mathrm{~mol} / \mathrm{L}$.

As shown in Figure 3A (inset), for pure MCF supports with different pore sizes (MCF-6.4, MCF-14.5, and MCF-30.1), the point of zero charge, $\mathrm{pH}_{p z c}$, is in the range 4 to 5.6. As a result of protein adsorption, the change of biocomposites acid-base properties into amphiphilic is observed with $\mathrm{pH}_{p z c}$ in the range 4.64-4.88 (Figure 3A). In the case of pure MCF-6.4, MCF-14.5 and MCF-30.1 their surfaces at experimental conditions (PBS, $\mathrm{pH}=7.4$ ) are slightly negatively charged with $Q_{s}$ ca. $-0.05,-0.06$, $-0.04 \mathrm{C} / \mathrm{m}^{2}$, respectively (inset in Figure $3 \mathrm{~A}$ ). It is interesting to note that the surface charge density after LYS adsorption increases up to $-0.08 \mathrm{C} / \mathrm{m}^{2}$ for LYS/MCF-6.4, $-0.15 \mathrm{C} / \mathrm{m}^{2}$ for LYS/MCF-14.5 and $-0.17 \mathrm{C} / \mathrm{m}^{2}$ for LYS/MCF-30.1 (Figure 3A,B). The presented results indicate the small negative surface charge for all studied MCF supports at $\mathrm{pH}=7.4$. Thus, regarding the positive charge of lysozyme at $\mathrm{pH}=7.4$, the electrical attraction between the silica surface and the protein molecule can be supposed. Considering high protein adsorption values, it should be assumed that the electrostatic attractive interactions play a significant role in the immobilization process [36]. In (Supplementary Material) the relation among the pore diameters and specific surface areas of MCF adsorbents and biocomposites, and the points of zero charge $\left(\mathrm{pH}_{p z c}\right)$ is demonstrated in Figure S3. One can find that the acid-base character of the studied pure silica surface changes in comparison to the silica modified by LYS. Generally, as demonstrated in Figure S3 (Supplementary Material), for MCF silica materials after adsorption of lysozyme $\mathrm{pH}_{p z c}$ stabilizes. 


\subsection{Thermal Analysis (TG/DSC/FTIR/MS)}

The use of thermogravimetry (TG), derivative thermogravimetry (DTG), and differential scanning calorimetry (DSC) is a widely applied method for characterizing the thermal properties by measuring changes in physical and chemical properties (transition, dehydration, decomposition) during the heating process of materials. By enhancing temperature the protein, degradation is induced, leading to the removal of organic material from the inorganic support. The mass loss during thermal decomposition corresponds to the amount of protein adsorbed on the support [37,38].

TG/DTG/DSC curves of thermal decomposition of native lysozyme, pure silica curriers, and silica/LYS composites in the air are presented in Figure $4 A, A^{\prime}-C, C^{\prime}$. The mass losses (TG), the corresponding derivatives (DTG), and differential scanning calorimetry values (DSC) for MCF-14.5, MCF-6.4, MCF-30.1 without and with immobilized protein analyzed in oxidation atmosphere are gathered in Tables 5 and 6. Basing on the presented results one can see that pure MCF materials decompose in one main step under oxidative conditions. The total mass losses in the range $185^{\circ} \mathrm{C}$ to $830{ }^{\circ} \mathrm{C}$ estimated for MCF-14.5, MCF-6.4, MCF-30.1 materials were about $1.57 \%, 3.09 \%$ and $1.03 \%$, respectively (Figure $4 \mathrm{~A}^{\prime}$ ). The LYS/MCF composites are thermally stable up to the temperature $\sim 165^{\circ} \mathrm{C}$ in the atmosphere of synthetic air. Afterwards, the decomposition of the LYS/MCF composites runs as two major stages in the temperature range $165-420-830^{\circ} \mathrm{C}$ with $T_{\max 1}$ (the maximum temperatures of mass loss in first decomposition step) and $T_{\max 2}$ (the maximum temperatures of mass loss in second decomposition step) given in Table 5. It should also be noted that for LYS/MCF composites, the weight loss $(1.2$ to $2 \%)$ in initial decomposition temperature $\left(M_{\text {loss }, I D T}\right) 30-165{ }^{\circ} \mathrm{C}$ is attributed to the removal of water (endothermic process, Figure 4A, Table 5). In turn, the mass loss in the first main step $\left(M_{\text {loss } 1}\right)$ at temperatures $165-420^{\circ} \mathrm{C}$ is related to the removal of weakly bound albumin from the silica supports (van der Waals forces) and in the second one $\left(M_{\text {loss } 2}\right)$ above $420^{\circ} \mathrm{C}$ for LYS/MCF composites are associated to the removal of protein molecules strongly linked with the silica materials (electrostatic interactions) [39,40]. TG/DTG analysis (Figure 4A,B and Table 5) for MCF-14.5/LYS composite shows that the first main decomposition step appears in the temperature range $165-420^{\circ} \mathrm{C}$ with $T_{\max 1} \sim 323^{\circ} \mathrm{C}$, and with the mass loss $17.3 \%$. The second step of decomposition is visible in the temperature range $420-830{ }^{\circ} \mathrm{C}$ with the mass loss of $10.8 \%$ occurred in $T_{\max 2} \sim 508^{\circ} \mathrm{C}$. Considerably smaller mass losses $13.4 \%, 9.9 \%\left(M_{\text {loss } 1}\right)$, and $8.9 \%, 8 \%\left(M_{\text {loss } 2}\right)$ were obtained for LYS/MCF-6.4, LYS/MCF-30.1 composites, respectively. For MCF-6.4 silica with a small pore size the first step of decomposition occurs with $T_{\max 1}$ $\sim 327^{\circ} \mathrm{C}$ and in the second step with $T_{\max 2} \sim 498^{\circ} \mathrm{C}$. Likewise, in the case of MCF-30.1 sample with wider pores the first and second stage of decomposition is found at $T_{\max 1} \sim 321{ }^{\circ} \mathrm{C}$ and $T_{\max 2} \sim 520^{\circ} \mathrm{C}$ (Table 5). These decomposition stages are directly connected to the presence of LYS in the studied materials. These results significantly confirm that increasing the adsorption of lysozyme on MCF leads to greater weight loss during the heating process of the studied biomaterials. This effect is greater for MCF-14.5 material with a pore diameter of about 3.5 times larger than the hydrodynamic diameter of protein $(4 \mathrm{~nm})$. It may be concluded that the total mass loss $\left(M_{\text {loss,TOTAL }}\right)$ for LYS/MCF-14.5 composite is ca. 5.7\% higher than for LYS/MCF-6.4, and almost 9.4\% greater in comparison to LYS/MCF-30.1.

Table 5. TG and DTG data obtained in air atmosphere for LYS/MCF composites.

\begin{tabular}{|c|c|c|c|c|c|c|}
\hline \multirow{3}{*}{ Material } & \multicolumn{4}{|c|}{ TG } & \multicolumn{2}{|c|}{ DTG } \\
\hline & $M_{l o s s, I D T}[\%]$ & $M_{l o s s 1}[\%]$ & $M_{\text {loss } 2}[\%]$ & $M_{\text {loss,TOTAL }}$ & $T_{\max 1}$ & $T_{\max 2}$ \\
\hline & $30-165\left[{ }^{\circ} \mathrm{C}\right]$ & $165-420\left[{ }^{\circ} \mathrm{C}\right]$ & $420-830\left[{ }^{\circ} \mathrm{C}\right]$ & & {$\left[{ }^{\circ} \mathbf{C}\right]$} & {$\left[{ }^{\circ} \mathrm{C}\right]$} \\
\hline LYS/MCF-14.5 & 1.2 & 17.3 & 10.8 & 29.3 & 323 & 508 \\
\hline LYS/MCF-6.4 & 1.3 & 13.4 & 8.9 & 23.6 & 327 & 498 \\
\hline LYS/MCF-30.1 & 2.0 & 9.9 & 8.0 & 19.9 & 321 & 520 \\
\hline
\end{tabular}

$M_{\text {loss,IDT }}$, mass loss at initial decomposition temperature; $M_{\text {loss } 1,2}$, mass loss in main (first or second) decomposition step $M_{\text {loss,TOTAL }}$, total mass loss; $T_{\max 1,2}$, maximum temperatures of mass loss in first or second decomposition step. 

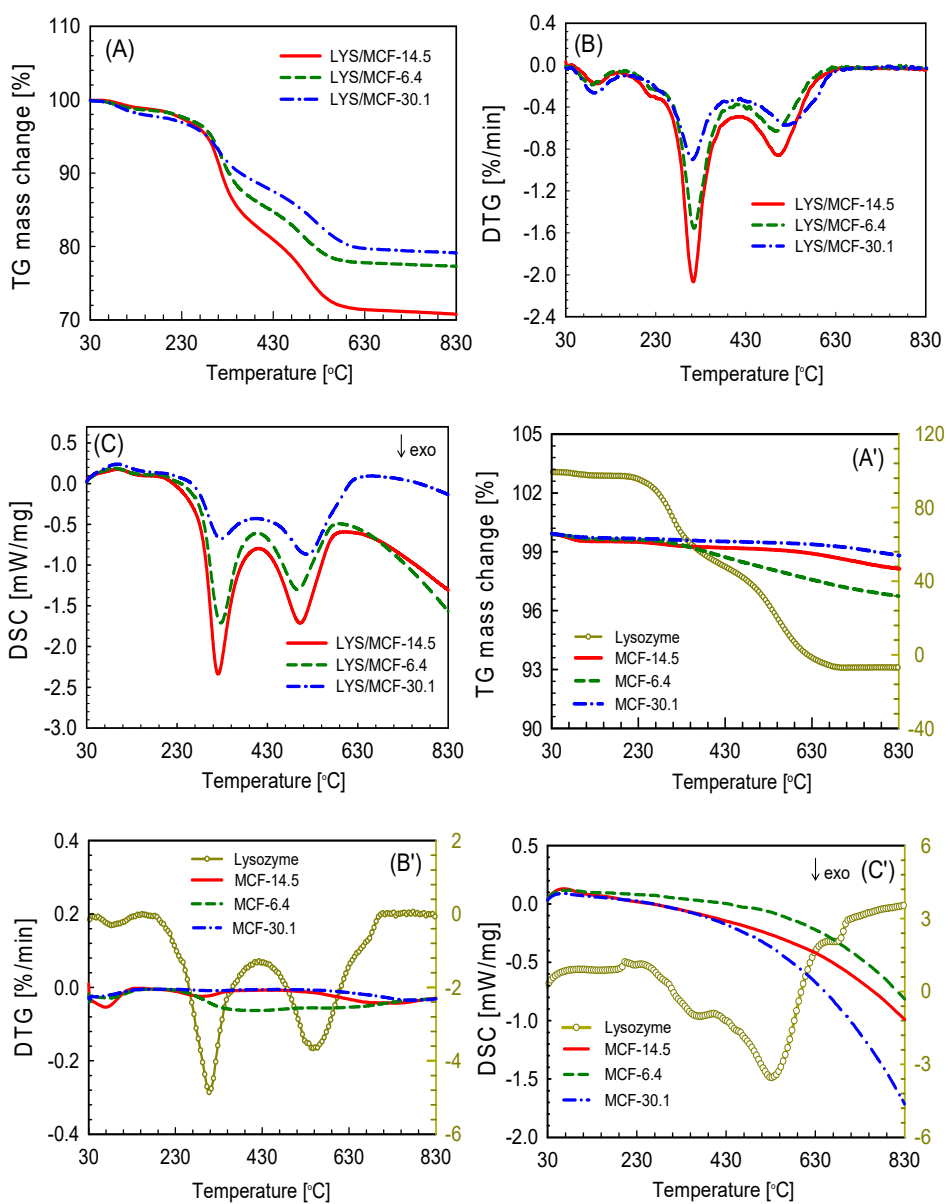

Figure 4. Thermogravimetric analyzer (TG) profiles in synthetic air for selected LYS/MCF composites (A), native protein and pure MCF supports $\left(\mathbf{A}^{\prime}\right)$; DTG curves in synthetic air for selected LYS/MCF composites (B), native lysozyme and pure MCF supports ( $\left.\mathbf{B}^{\prime}\right)$; DSC curves for biocomposites $(\mathbf{C})$, pure lysozyme and MCF silica supports $\left(\mathbf{C}^{\prime}\right)$.

Table 6. DSC data obtained in synthetic air for MCF materials before and after lysozyme adsorption.

\begin{tabular}{|c|c|c|c|c|c|c|c|c|}
\hline \multirow[b]{2}{*}{ Material } & \multicolumn{7}{|c|}{ DSC } & \multirow[b]{2}{*}{$\begin{array}{c}\Delta H \\
{[\mathrm{~J} / \mathrm{g}]}\end{array}$} \\
\hline & $\begin{array}{c}T_{\text {onset } 1} \\
{\left[{ }^{\circ} \mathrm{C}\right]}\end{array}$ & $\begin{array}{c}T_{\text {peak } 1} \\
{\left[{ }^{\circ} \mathrm{C}\right]}\end{array}$ & $\begin{array}{l}T_{\text {end1 }} \\
{\left[{ }^{\circ} \mathrm{C}\right]}\end{array}$ & $\begin{array}{c}\Delta H \\
{[\mathrm{~J} / \mathrm{g}]}\end{array}$ & $\begin{array}{c}T_{\text {onset } 2} \\
{\left[{ }^{\circ} \mathrm{C}\right]}\end{array}$ & $\begin{array}{c}T_{\text {peak } 2} \\
{\left[{ }^{\circ} \mathrm{C}\right]}\end{array}$ & $\begin{array}{c}T_{\text {end } 2} \\
{\left[{ }^{\circ} \mathrm{C}\right]}\end{array}$ & \\
\hline LYS/MCF-14.5 & 283 & 321 & 366 & -654 & 448 & 503 & 587 & -452 \\
\hline LYS/MCF-6.4 & 282 & 327 & 372 & -491 & 447 & 498 & 588 & -338 \\
\hline LYS/MCF-30.1 & 270 & 328 & 373 & -197 & 455 & 519 & 620 & -408 \\
\hline
\end{tabular}

$T_{\text {onset }}$, temperature of the decomposition initiation; $T_{\text {peak }}$, maximum decomposition temperature; $T_{\text {end }}$, final decomposition temperature; $\Delta H$, the heat generated during the decomposition process obtained by the integration of the thermal peaks.

Additionally, the DSC curves (Figure 4C) for three studied MCF/protein composites reveal two exothermic peaks in the region of high temperatures. The presence of the first exothermic peak situated in the range $270-373{ }^{\circ} \mathrm{C}$ with $T_{\text {peak }}$ ca. $321-328^{\circ} \mathrm{C}$, and the second exothermic peak in the range 447-620 ${ }^{\circ} \mathrm{C}$ with $T_{\text {peak }}$ ca. $498-519{ }^{\circ} \mathrm{C}$ (Table 6) is directly connected with the main decomposition step of LYS, which corresponds to the TG mass losses. Also, the characteristic temperatures $\left(T_{\text {onset }}\right.$, the temperature of decomposition initiation; $T_{\text {peak }}$, the maximum decomposition temperature; $T_{\text {end }}$, the final decomposition temperature) obtained from DSC (Figure 4C and Table 6) are comparable to those obtained from TG analysis.

To explain the thermal decomposition routes, as well as its mechanisms for the studied biomaterials, the analysis of the gaseous products emitted during their decomposition was conducted by TG/FTIR 
and TG/QMS technique. 3D FTIR spectrum of the studied LYS/MCF composites gathered at the temperatures corresponding to the main thermal degradation stages on the DSC curves ( $T_{\text {peak } 1}$ and $\left.T_{\text {peak } 2}\right)$ in the air atmosphere are presented in Figure 5A-C. The typical QMS spectra of the characteristic ion currents $(\mathrm{m} / \mathrm{z})$ of gaseous products formed during the decomposition of three selected MCF supports with immobilized lysozyme obtained in the air are shown in Figure 6A-G.

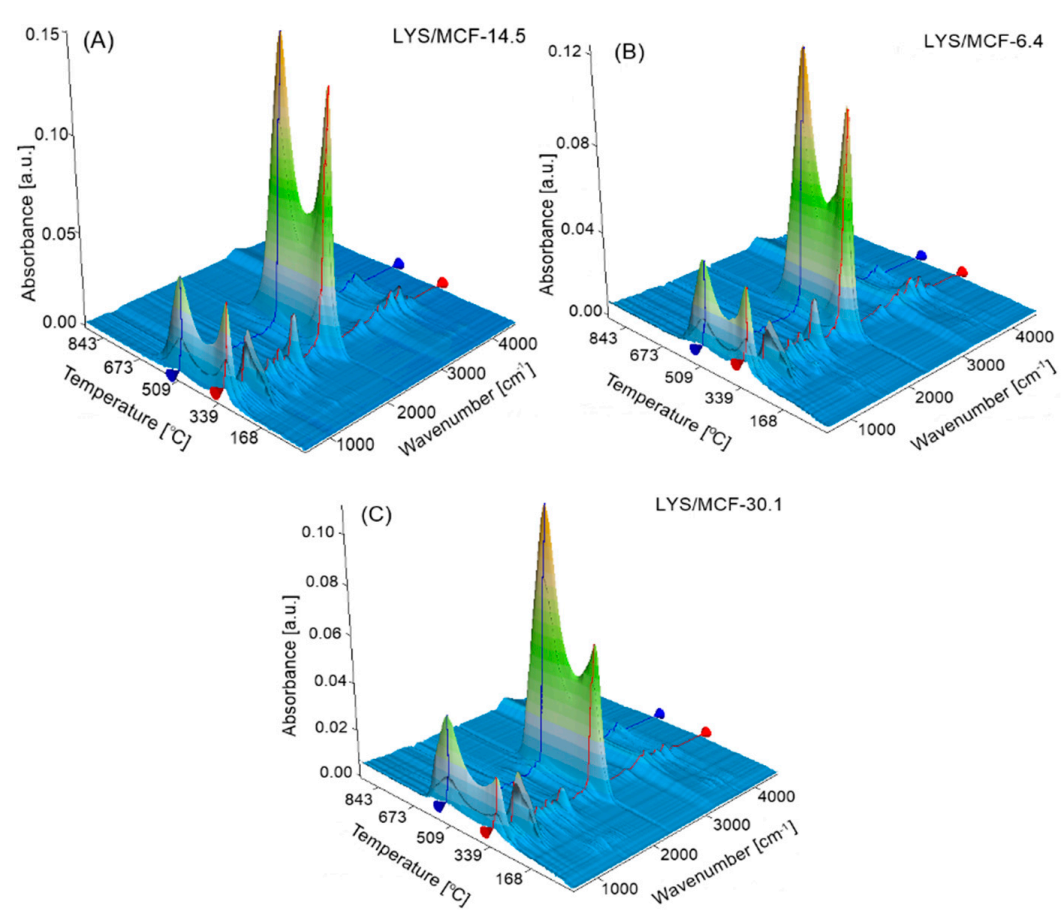

Figure 5. 3D FTIR spectrum of (A) LYS/MCF-14.5, (B) LYS/MCF-6.4, and (C) LYSMCF-30.1 composites registered at two peaks temperatures $T_{\text {peak } 1}$ (red line) and $T_{\text {peak } 2}$ (blue line) marked from DSC curves.

Figure $6 \mathrm{H}$ presents QMS profiles of the main product, $\mathrm{H}_{2} \mathrm{O}$, formed during the decomposition of pure MCF-14.5, MCF-6.4, MCF-30.1 materials. According to these results for all native silica materials, the ion current signal at $m / z=18$ is observed which is characteristic for water forming as the main decomposition product (Figure 6H). It is confirmed by the FTIR spectra in the ranges $3570 \mathrm{~cm}^{-1}$ to $3900 \mathrm{~cm}^{-1}, 1390 \mathrm{~cm}^{-1}$ and $1870 \mathrm{~cm}^{-1}$ corresponding to rotation/vibration transition within water molecules in the vapor phase-stretching vibration and symmetric bending.

TG/QMS/FTIR results significantly indicate the formation of various gaseous products during the decomposition process of three studied biocomposites. At the main thermal degradation stages at $T_{\text {peak } 1}$ and $T_{\text {peak } 2}$, the absorption bands at $2310 \mathrm{~cm}^{-1}, 2360 \mathrm{~cm}^{-1}$ and $669 \mathrm{~cm}^{-1}$ characteristics for carbon dioxide (Figure 5A-C) are observed. Two first bands correspond to $\mathrm{R}$ and P-branches of asymmetric stretching vibration and the third band is connected with symmetric bending vibrations of $\mathrm{CO}_{2}$. The presence of this compound is also evidenced in the MS spectra of the characteristic ion current at $\mathrm{m} / \mathrm{z}=44$ (Figure 6A). Moreover, the absorption bands at $3735 \mathrm{~cm}^{-1}, 3503 \mathrm{~cm}^{-1}, 1756 \mathrm{~cm}^{-1}$ correspond to the $\mathrm{O}-\mathrm{H}$ stretching vibrations of water molecules in the vapor phase (both stretching vibrations and symmetric bending) (Figure 5). The MS signal corresponding to $\mathrm{m} / \mathrm{z}=18$ confirms the appearance of water vapor in the mixture of gases evolved during thermal decomposition of protein/silica composites (Figure 6B). Among the decomposition products, one can find also the signals recorded for $\mathrm{SO}_{2}($ at $m / z=64$ ) (Figure $6 \mathrm{C}$ ) which comes from the sulfonate groups in biocomposites. It is also confirmed by the FTIR absorption bands at ca. $1370 \mathrm{~cm}^{-1}$ (asymmetric stretching vibration of the $\mathrm{SO}_{2}$ molecule). In this decomposition stage, the FTIR absorption bands at $2896 \mathrm{~cm}^{-1}$ and $2972 \mathrm{~cm}^{-1}$ (Figure 5) are found which may be attributed to the $\mathrm{CH}$ stretching vibrations characteristic for the aliphatic groups appearing in the gaseous decomposition products of protein. They give the MS signal 
$m / z=15$ (Figure 6D) corresponding to methyl groups $\mathrm{CH}_{3}$. Moreover, the FTIR absorption band at ca. $1617 \mathrm{~cm}^{-1}$ is also identified. It corresponds to the asymmetric stretch of $\mathrm{NO}_{2}$ (the signal at $\mathrm{m} / \mathrm{z}=46$ on the MS spectrum, Figure 6E). Additionally, among the products observed during the thermal decomposition $\mathrm{NH}_{3}$ presence at $m / z=17$ (Figure $6 \mathrm{~F}$ ) is detected and proved by FTIR absorption bands of medium intensities at $930 \mathrm{~cm}^{-1}$ and $965 \mathrm{~cm}^{-1}$ (maxima of rotational branches of the symmetric bending vibration), and $1626 \mathrm{~cm}^{-1}$ (the Q-branch of asymmetric bending vibration) (Figure 5). Moreover, the presence of $\mathrm{HCN}$ in the gaseous phase is found on the MS spectrum at $m / z=27$, and on the FTIR absorption band at $714 \mathrm{~cm}^{-1}$ (Figures 5 and 6G).
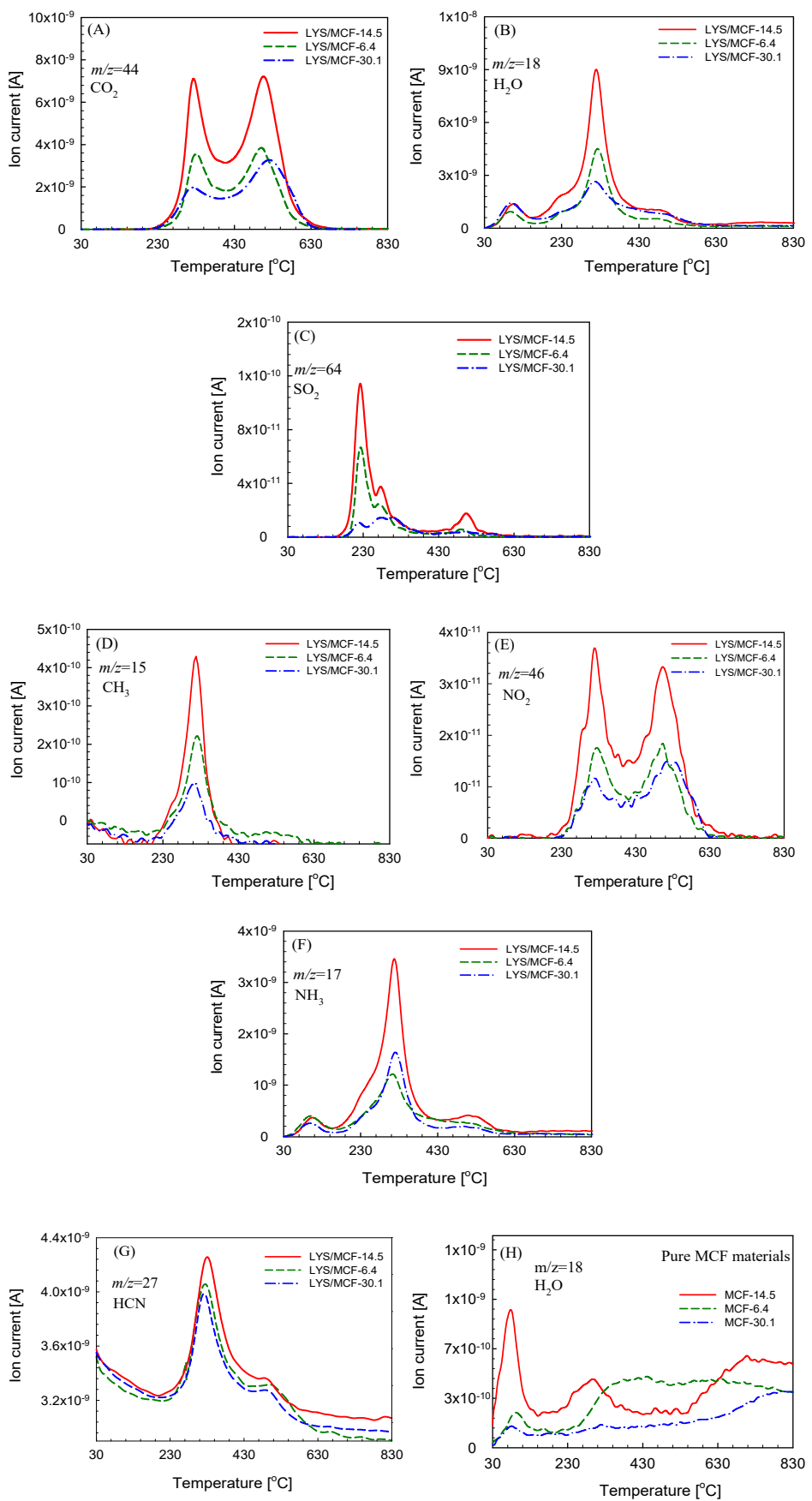

Figure 6. QMS profile of gaseous products emitted during decomposition of three selected LYS/MCF-14.5, LYS/MCF-6.4, LYS/MCF-30.1 composites vs. temperature at $m / z$ : (A) $15\left(\mathrm{CO}_{2}\right)$; (B) 18 $\left(\mathrm{H}_{2} \mathrm{O}\right) ;(\mathrm{C}) 64\left(\mathrm{SO}_{2}\right) ;(\mathbf{D}) 15\left(\mathrm{CH}_{3}\right) ;(\mathrm{E}) 46\left(\mathrm{NO}_{2}\right) ;(\mathbf{F}) 17\left(\mathrm{NH}_{3}\right) ;(\mathrm{G}) 27(\mathrm{HCN})$ in air atmosphere; (H) MS profile of $\mathrm{H}_{2} \mathrm{O}$ vs. temperature for pure MCF-14.5, MCF-6.4 and MCF-30.1 supports. 
It is worth noting that for LYS/MCF-14.5 the QMS spectra show the higher ion currents $(\mathrm{m} / z=15$, $17,18,27,44,46,64)$ of gaseous products formed during the decomposition of protein/silica material: $\mathrm{CH}_{3}, \mathrm{NH}_{3}, \mathrm{H}_{2} \mathrm{O}, \mathrm{HCN}, \mathrm{CO}_{2}, \mathrm{NO}_{2}, \mathrm{SO}_{2}$ in comparison to LYS/MCF-6.4 and LYS/MCF-30.1. It confirms that more protein molecules are immobilized on the MCF-14.5 support. The same conclusions are supported by the analysis of TG/FTIR spectra for the studied biomaterials by higher intensities of absorption bands. It may be concluded that this effect decreases in the series: MCF-14.5 > MCF-6.4 > MCF-30.1. These results are in good agreement with the $\mathrm{N}_{2}$ adsorption/desorption analysis and batch adsorption experiment.

\subsection{Microscopic Analysis (SEM, TEM)}

The scanning electron microscopy (SEM) and the high-resolution transmission electron microscopy HRTEM-BF (bright field) allow comparing the surface morphology, texture, and micro-nanostructure of the native MCF supports with different pore sizes and protein/silica composites. The two-dimensional (2D) micro-nano surface morphology visualization of the pure MCF-6.4, MCF-14.5, MCF-30.1 supports, and the biocomposites registered by SEM are presented in Figure $7(\mathrm{~A}-\mathrm{C})$ and Figure $7\left(\mathrm{~A}^{\prime}-\mathrm{C}^{\prime}\right)$, respectively. As can be seen, the lysozyme immobilization on the silica support with different pore sizes changes the grain surface morphology. In the case of all biocomposites the surface becomes smoother and more uniform comparing with the pure silica material [41]. Moreover, one can observe that the surface roughness changes as follows: MCF-6.4 > MCF-14.5 MCF-30.1. This observation confirms the changes in adsorption density obtained from the batch adsorption experiment (see Figure 1D). Figure 8A-C shows a comparison of TEM texture/topography micrographs at nano-level of pure MCF-6.4, MCF-30.1, and MCF-14.5 silica support as well as LYS/MCF-14.5 composite (Figure 8C'). It can be seen that HRTEM-BF micrographs for pure MCF-14.5, MCF-6.4, and MCF-30.1 silica materials confirm a porous structure of studied materials with regular 3D pore system with large spherical cells interconnected by narrow interconnectivities. The pore diameter estimated from HRTEM micrographs is $\sim 15 \mathrm{~nm}$ for MCF-14.5, $\sim 7 \mathrm{~nm}$ for MCF-6.4 and $\sim 31 \mathrm{~nm}$ for MCF-30.1, which is consistent with $\mathrm{N}_{2}$ sorption parameters. Moreover, the TEM micrographs show the immobilized lysozyme (as a circle-spiral form) on the surface of the MCF-14.5 support (Figure 8C') [41].

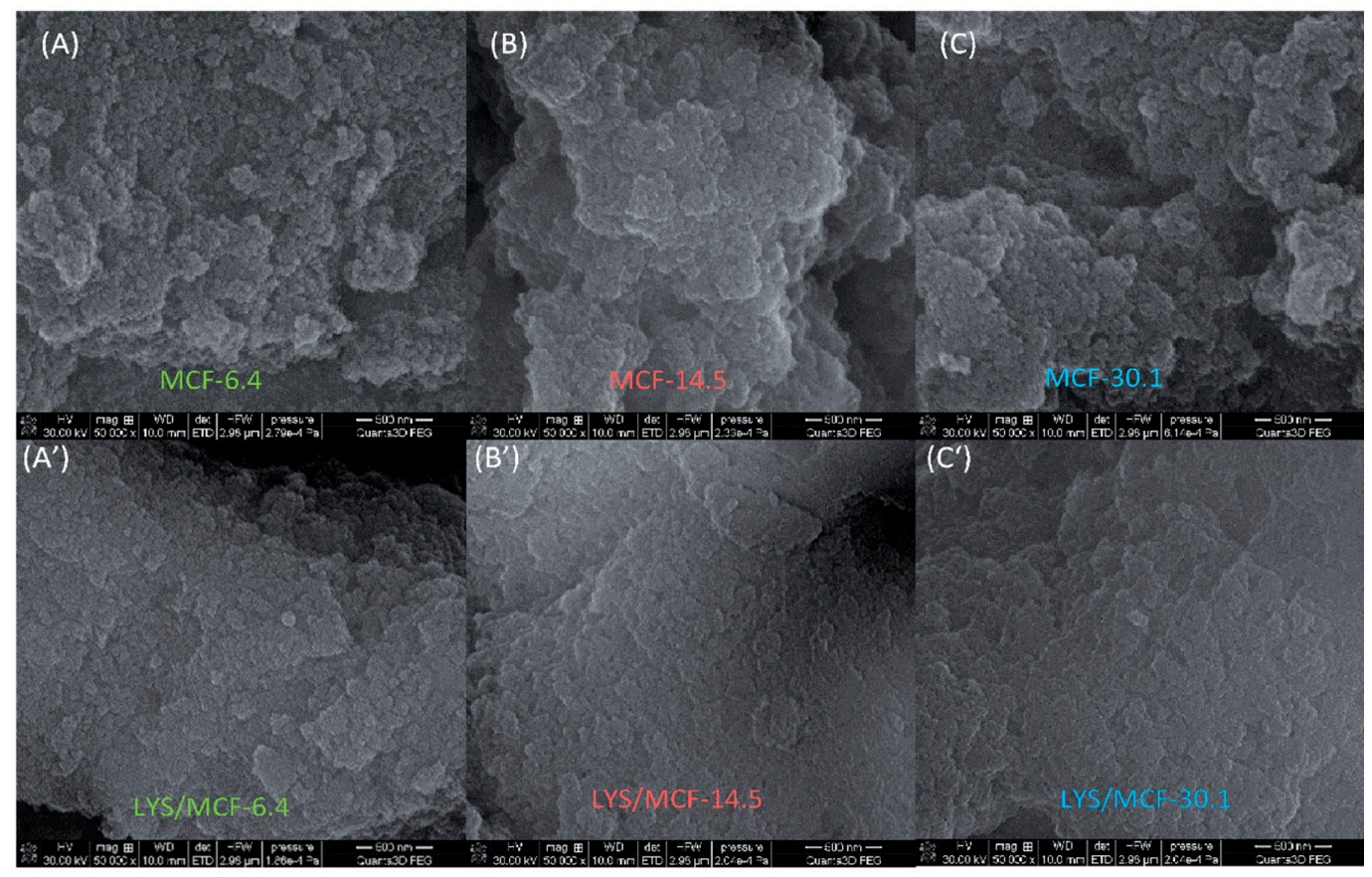

Figure 7. SEM micrographs of MCF-6.4 (A, magnification 50,000), MCF-14.5 silica (B, magnification 50,000), and MCF-30.1 (C, magnification 50,000) and after protein adsorption ( $\mathbf{A}^{\prime}, \mathbf{B}^{\prime}, \mathbf{C}^{\prime}$, magnification $50,000)$, respectively. 


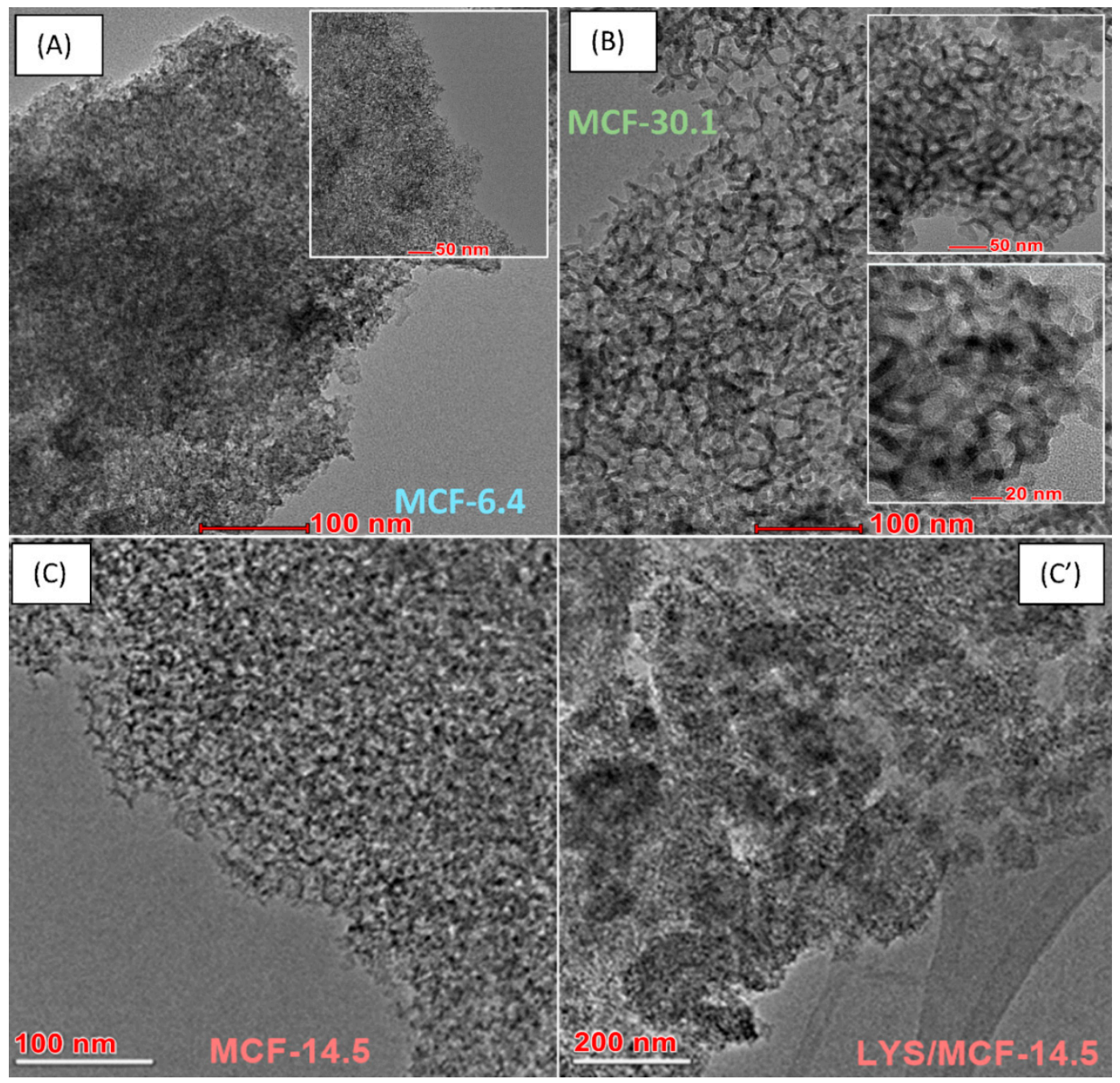

Figure 8. (A) HRTEM-BF micrographs showing the surface morphology and nanostructure of the MCF-6.4 (A), MCF-30.1 (B), and MCF-14.5 support before (C), and $\left(\mathbf{C}^{\prime}\right)$ after immobilization of LYS molecules.

\section{Materials and Methods}

\subsection{Reagents}

Lysozyme from chicken egg white (lyophilized powder, protein $\geq 90 \%, \geq 40,000$ units $/ \mathrm{mg}$ protein Cat. No. L6876) and 0.1 M phosphate buffer saline $\mathrm{pH}=7.4$, (BioPerformance Certified Buffers, Cat. No. P5368) were obtained from Sigma-Aldrich (Oakville, ON, Canada). The non-ionic triblock copolymers Pluronic PE9400 $\left(\mathrm{EO}_{21} \mathrm{PO}_{47} \mathrm{EO}_{21}, \mathrm{M}_{\mathrm{av}}=4600\right)$ from BASF (Baden Aniline and Soda Factory, Warsaw, Poland) and Pluronic P123 $\left(\mathrm{EO}_{20} \mathrm{PO}_{70} \mathrm{EO}_{20}, \mathrm{M}_{\mathrm{w}}=5800\right)$ from Sigma-Aldrich (Oakville, ON, Canada) were used as structure-directing agents. Tetraethylorthosilicate used as a silica source (TEOS $98 \%), 1,3,5$-trimethylbenzene (TMB) as a pore expanding agent, ammonium fluoride, $\left(\mathrm{NH}_{4} \mathrm{~F} \geq 98.0 \%\right)$ as a tuning window pore size-mineralizing agent, hydrochloric acid $(37 \%)$ and other reagents of analytical grade were purchased from Sigma-Aldrich (Oakville, ON, Canada) and used without further purification. Water was purified using a Millipore apparatus (resistivity of $18.2 \mathrm{M} \Omega \cdot \mathrm{cm}$ at $25^{\circ} \mathrm{C}$ ).

Lysozyme with its well-determined structure is a small molecular protein $(14.3 \mathrm{kDa})$ with a hydrodynamic radius of $\sim 2 \mathrm{~nm}$ and is composed of a single polypeptide chain of 129 amino acids in the form of five $\alpha$-helices, three antiparallel $\beta$-sheets and a large number of random coils and $\beta$-turns $[42,43]$. It has a prolate spheroid shape with two characteristic cross-sections: a side of approximate dimensions 
$4.5 \times 3.0 \mathrm{~nm}^{2}$ (shape similar to an ellipsoid) and an end of dimensions $3.0 \times 3.0 \mathrm{~nm}^{2}$ [44]. The isoelectric point for lysozyme is $\mathrm{pH}_{\mathrm{IEP}} \sim 11$, at $\mathrm{pH}=7$ it is positively charged [45,46]. This enzyme has high structural stability and inflexibility within $\mathrm{pH}$ wide range 1.5 to 12 because the rigidity of the single-chained LYS molecule is imposed by four internal disulphide bonds that help maintain its tertiary structure [47]. This globular protein belongs to the family of hydrolases which, thanks to its biological function (the hydrolysis of the polysaccharide forming the bacterial cell wall), can be applied as an antimicrobial, anti-inflammatory, antiviral, antiseptic, antitumor agents [48].

\subsection{Synthesis of Mesocellular Foam}

Mesoporous MCF silica adsorbents with different pore structures were synthesized according to a previously published procedure $[49,50]$ with some modifications described in the papers $[51,52]$. In the preparation of pure MCF support, Pluronic (P123 or PE9400) (4 g) was dissolved in $180 \mathrm{~mL}$ of $1.6 \mathrm{M}$ aqueous $\mathrm{HCl}$ solution and stirred over $2 \mathrm{~h}$ at room temperature. Then, the established amount of TMB (polymer/TMB mass ratios were varied) was introduced to the mixture, and the resulting liquid was heated to $40{ }^{\circ} \mathrm{C}$ under continuous vigorous stirring by using a digitally controlled mechanical stirrer ( $250 \mathrm{rpm}, 45 \mathrm{~min}$ ). Then, the desired amounts of TEOS (the mass proportions of polymer/TEOS were changed) was introduced to the reaction mixture, and it was stirred for another $20 \mathrm{~h}$ at the same temperature. The resulting solution was transferred to an autoclave and aged at elevated temperatures (110-120 ${ }^{\circ} \mathrm{C}$ ) for 24-144 $\mathrm{h}$. In the case of some samples, $46 \mathrm{mg}$ of $\mathrm{NH}_{4} \mathrm{~F}$ in $0.3 \mathrm{~mL} \mathrm{H}_{2} \mathrm{O}$ was added if desired as the mineralizing agent to increase the window pore size. Finally, the synthesized precipitate was thoroughly washed with distilled water and dried in air. Detailed synthesis conditions of MCF samples are given in Table S2 (Supplementary Material).

\subsection{Adsorption Experiment}

\subsubsection{Adsorption Equilibrium}

The equilibrium studies of LYS adsorption on the series of MCF adsorbents with varied porosity were performed by using the static methods. Before the experiment, the MCF material was dried at $150{ }^{\circ} \mathrm{C}$. A series of stock protein solutions at different concentrations $(1-5 \mathrm{mg} / \mathrm{mL})$ was prepared by dissolving appropriate amounts of protein in phosphate-buffered saline solutions at $\mathrm{pH}=7.4$. Then, $100 \mathrm{mg}$ of pure MCF materials were contacted with the protein solution. The Erlenmeyer flasks with resulting suspensions were placed in the incubator shaker (New Brunswick Scientific Innova 40R Model, Eppendorf AG, Hamburg, Germany) and stirred at $25^{\circ} \mathrm{C}$ at $110 \mathrm{rpm}$ speed until equilibrium was reached $(24 \mathrm{~h})$. After attaining equilibrium the equilibrium concentrations of proteins were determined using UV-Vis spectrophotometer Cary 100 (Varian Inc., Melbourne, Australia) at the wavelength of $281 \mathrm{~nm}$. The adsorbed amount of protein was calculated from the mass balance equation:

$$
a_{e q}=\frac{\left(c_{o}-c_{e q}\right) \cdot V}{w}
$$

where: $a_{e q}$ is the equilibrium adsorbed amount $[\mathrm{mg} / \mathrm{g}], c_{o}$ is the initial concentration of protein solution $[\mathrm{mg} / \mathrm{mL}], c_{e q}$ is the protein equilibrium concentration $[\mathrm{mg} / \mathrm{mL}], V$ is the solution volume $[\mathrm{ml}]$, and $w$ is the MCF mass [mg].

The experimental protein adsorption isotherms from aqueous solutions were analyzed by applying the Generalized Langmuir (GL) isotherm equation [53]:

$$
a_{e q} / a_{m}=\left[\frac{\left(K c_{e q}\right)^{m}}{1+\left(K c_{e q}\right)^{m}}\right]^{m / n}
$$


where: $a_{m}$ is the adsorption capacity; $m, n$ is the heterogeneity parameters $(0<m, n \leq 1)$ describing the shape (asymmetry) of adsorption energy distribution function; $K$ is the equilibrium constant related to characteristic adsorption energy.

GL equation is applied for the analysis of the localized physical adsorption on energetically heterogeneous solids. For the specific values of $m$ and $n$ parameters GL equation changes form into 4 simpler isotherms equations: Langmuir (L) (GL: $m=n=1$ ); Langmuir-Freundlich (LF) (GL: $0<m=$ $n \leq 1)$; Generalized Freundlich (GF) (GL: $n=1,0<m \leq 1$ ); Tóth (T) (GL: $m=1,0<n \leq 1$ ).

\subsubsection{Adsorption Kinetics}

The adsorption kinetic measurements were performed by means of the UV-Vis spectrophotometer Cary 100 (Varian Inc., Melbourne, Australia) with a quartz flow cell to analyze a solute concentration in a closed system [54-56]. The LYS solution $(200 \mathrm{~mL})$ with an established initial concentrate on of $0.4 \mathrm{mg} / \mathrm{mL}$ was conducted with a known amount of mesoporous silica $(250 \mathrm{mg})$ in a thermostated vessel at constant temperature $\left(25^{\circ} \mathrm{C}\right)$. The suspension was stirred during the experiment by applying a digitally controlled mechanical stirrer $(110 \mathrm{rpm})$. At definite time intervals the sample of protein solution was collected automatically to the flow cell of the spectrophotometer and the absorbance UV spectra in the wavelength range $200-400 \mathrm{~nm}$ were collected. Afterwards, the protein solution was returned to the reaction vessel. Finally, the concentration vs. time and the adsorption vs. time profiles for the protein adsorption system were calculated from the obtained spectra.

The measured kinetic data were analyzed by using the multi-exponential (m-exp) equation [30]:

$$
c=\left(c_{0}-c_{e q}\right) \sum_{i=1}^{n} f_{i} \exp \left(-k_{i} t\right)+c_{e q}
$$

where: $c$-the actual adsorbate concentration, $k_{i}$-the rate constant $(i=1,2, \ldots, n), f_{i}$ - the coefficient determining a fraction of a solute adsorbed with rate $k_{i}$. Moreover, the adsorption kinetic half-time was estimated as a time needed for attaining $\frac{1}{2}$ of concentration change.

The kinetic experimental data were also studied by applying the other kinetic equations and models: first-order (FOE), second-order (SOE), mixed-order (MOE), fractal first-order (f-FOE), fractal second-order (f-SOE), fractal mixed-order (f-MOE) equations, and the intraparticle diffusion (IDM, Crank) and pore diffusion (PDM, McKay) models (Supplementary Material) [30]. The non-linear LSQ optimization was applied in the calculations taking into account the difference between the experimental and fitted adsorbate concentrations.

\subsection{Potentiometric Titration}

The surface acid-base character (surface charge and $\mathrm{pH}$ of zero charge $-p H_{p z c}$ ) of the pure MCF materials and MCF with the immobilized LYS were determined by potentiometric titration. The measurements were carried out in the thermostatic vessel at $25^{\circ} \mathrm{C}$ applying a Dosimat 765 automatic burette (Metrohm, Herisau, Switzerland) connected with a precision $\mathrm{pH}$-meter (PHM 240, Radiometer, Copenhagen, Denmark). The details of the potentiometric titration measurements for pure MCF sorbents were as follows: $30 \mathrm{~mL}$ of the stock electrolyte $(0.1 \mathrm{M} \mathrm{NaCl})$ was acidified with $0.3 \mathrm{~mL}$ of $0.5 \mathrm{M} \mathrm{HCl}$ solution and transferred into a thermostatic quartz vessel. To prevent contamination with $\mathrm{CO}_{2}$, the pure nitrogen flow was used throughout the titration (1-2 bubbles per second). The determined amounts of MCF samples $(0.1 \mathrm{~g})$ were added into the electrolyte solution and then the resulting suspension of adsorbent was titrated by using $0.2 \mathrm{M} \mathrm{NaOH}$ recording $\mathrm{pH}$ changes.

The potentiometric titration experiment for MCF adsorbents with immobilized lysozyme was carried out as follows: the MCF samples $(0.1 \mathrm{~g})$ were added to a thermostatic vessel containing $30 \mathrm{~mL}$ of lysozyme solution of concentration $5 \mathrm{mg} / \mathrm{mL}$ in $0.1 \mathrm{M} \mathrm{NaCl}$. Then, the system was acidified $(0.3 \mathrm{~mL}$ of $0.5 \mathrm{M} \mathrm{HCl}$ solution), and the adsorption process was carried out at $25^{\circ} \mathrm{C}$ for $24 \mathrm{~h}$ and finally the resulting mixture protein/sorbent suspension was also titrated using $0.2 \mathrm{M} \mathrm{NaOH}$. 
The obtained potentiometric titration curves ( $\mathrm{pH}$ solution vs. $\mathrm{NaOH}$ volume) for MCF materials and LYS/MCF systems were converted into the surface charge density curves, using the equation [57]:

$$
q_{s}=\frac{F \cdot \Delta n_{H^{+}}}{S_{B E T}}
$$

where: $q_{s}$ 一the surface charge, $\Delta n_{H+}$ 一the ion mole number for $1 \mathrm{~g}$ of material, $F$-the Faraday's constant, $S_{B E T}$-the specific surface area of adsorbents.

\subsection{Nitrogen Adsorption/Desorption Isotherms}

The porous structure evaluation of mesoporous silica before and after lysozyme adsorption were thoroughly characterized by using a low-temperature adsorption/desorption of nitrogen at $-196{ }^{\circ} \mathrm{C}$ applying the automatic ASAP 2020 sorption analyzer (Micromeritics Instrument Corp., Norcross, GA, USA). Prior to the measurement, the pure MCF supports and LYS/MCF composites were outgassed $(4 \mu \mathrm{mHg})$, respectively, at $150{ }^{\circ} \mathrm{C}$ and $30^{\circ} \mathrm{C}$ for $24 \mathrm{~h}$ in degas port of analyzer. The obtained adsorption/desorption isotherms were used to evaluate the porous structure of the studied $\mathrm{MCF}$ adsorbents as well as protein/silica composites. The specific surface area $\left(S_{B E T}\right)$ was calculated using the Brunauer-Emmett-Teller (BET) equation. Meanwhile, the total pore volumes $\left(V_{t}\right)$ were estimated from the single point adsorption value at the relative pressure $\left(p / p_{0}\right)$ of 0.99 . To assess the values of the external surface area $\left(S_{\text {ext }}\right)$ and the mesopore volume $\left(V_{m e s}\right)$ the $\alpha_{s}$ plot was used [58]. Calculation of the pore size distributions (PSD) were determined using the adsorption and desorption branches of the isotherms by means of the Barrett-Joyner-Halenda (BJH) procedure for cylinder pores [59]. The pore diameters were derived from the PSD maxima (mode, $\left.D_{m o}\right)$ and PSD average $\left(D_{a v}\right)$. In turn, the mean hydraulic pore diameters were calculated from the BET surface areas and total pore volumes $D_{h}=4 \cdot V_{t} / S_{B E T}$.

\subsection{Scanning Electron Microscopy (SEM) and Transmission Electron Microscopy (TEM)}

The surface morphology, topography, and structure at the micro and nano level of silica support without and with adsorbed protein was examined by using the scanning electron microscope (SEM) Quanta 3D FEG (FEI, Field Electron and Ion Co., Hillsboro, OR, USA) and the high-resolution transmission electron microscope S/TEM Titan3TM G2 60-300 (FEI Company, Hillsboro, OR, USA) equipped with a field-emission electron gun (FEG) in high-resolution bright-field imaging (HRTEM-BF) in TEM mode.

\subsection{Thermal Analysis Coupled with FTIR and MS}

The thermal analysis was used to examine the thermal stability, behavior, and decomposition of the MCF materials before and after LYS adsorption, as well as to determine the presence of protein on the silica surface or in the pores. The thermal experiment was carried out on the apparatus STA 449 Jupiter F1 (Netzsch, Selb, Germany). The samples ( 18 mg) in aluminum crucibles were heated in the temperature range $30-950{ }^{\circ} \mathrm{C}$ with a heating rate of $10^{\circ} \mathrm{C} / \mathrm{min}$ under a dynamic atmosphere of synthetic air with a flow rate of $50 \mathrm{~mL} / \mathrm{min}$. The sensor thermocouple type $\mathrm{S}$ TG-DSC and empty $\mathrm{Al}_{2} \mathrm{O}_{3}$ crucible as a reference were used. The identification of gas products emitted during decomposition of the studied materials was detected and analyzed by quadrupole mass spectrometer QMS 403C Aëolos (Netzsch, Selb, Germany) and Fourier transform infrared spectroscopy FTIR spectrometer Brucker (Ettlingen, Germany) coupling on-line to STA instrument. The QMS data were collected in the range of 10 to $300 \mathrm{amu}$. The FTIR spectra in the spectral range $600-4000 \mathrm{~cm}^{-1}$ with 16 scans per spectrum at a resolution $4 \mathrm{~cm}^{-1}$ were recorded. 


\section{Conclusions}

The synthesized series of mesoporous MCF silica supports differentiated by pore diameters $(6-30 \mathrm{~nm})$ and surface areas $\left(250-720 \mathrm{~m}^{2} / \mathrm{g}\right)$ were applied for lysozyme immobilization by physical adsorption. For the first time, special attention was paid to the correlation between the MCF pore size and specific surface area, and lysozyme adsorption capacity and rate. The obtained results allow to optimize/design the structural characteristics of the solid support with respect to biomolecule adsorption and surface density for potential biomedical/biophysical applications. We found that the strongest adsorption was obtained for MCF-14.5 with the medium pore size which might be explained by the optimum relation of lysozyme molecular size and support pore diameter responsible for the increase of the adsorption forces. In the case of other materials with lower and higher pore sizes, the protein adsorbed amount decreased proportionally to a relation: pore diameter/protein diameter. The lysozyme adsorption process was the slowest for MCF-6.4 with the narrowest pores due to the hindered diffusion of protein molecules into the support pores. However, it is the quickest for MCF-30.1 with the largest pores facilitating the diffusion and adsorption. In the case of MCF-14.5, the adsorption process is slightly slower in comparison to MCF-30.1 which means that the pore sizes of this material do not disturb protein diffusion. The kinetic profiles for MCF-30.1 and MCF-6.4 achieved the comparable close to equilibrium adsorption values, however, for MCF-14.5 the equilibrium adsorption was higher. The changes in pore characteristics after lysozyme adsorption revealed that the protein molecules were adsorbed inside the channels of mesoporous adsorbents as well as located on the surface. Considering the positive charge of lysozyme at $\mathrm{pH}=7.4$ and the negative charge of silica, one can assume that the electrostatic attractive interactions play a significant role in the immobilization process. After protein adsorption $\mathrm{pH}_{p z c}$ for biomaterials stabilizes. The microscopic analyses revealed that topography, texture, and micro/nanostructure of the biocomposite surface were completely different from that of pure silica. The morphology and texture of the biocomposite surface were less porous, more homogeneous, and flat. The differences in protein adsorption and surface density for the biocomposites of various pore sizes are evident.

In further research, we will focus on estimating the LYS activity after adsorption on the mesoporous support and on studying the possible pore size effect to design a protein-containing biocomposite with better stability/activity for attaining effective mesoporous support for enzyme delivery and potential biotechnological applications [60].

Supplementary Materials: Supplementary Materials can be found at http://www.mdpi.com/1422-0067/21/15/ 5479/s1. Figure S1. (A) Comparison of nitrogen adsorption/desorption isotherms for selected MCF materials with different pore sizes (MCF-6.4 nm, MCF-14.5 nm, MCF-30.1 nm). (B, C) Pore size distributions calculated by using BJH method for the adsorption and desorption branches of isotherms. Figure S2. (A) Comparison of N2 adsorption/desorption isotherms before and after LYS adsorption for MCF-14.5, and MCF-6.4, MCF-30.1 (inset plots). (B) Differential pore size distributions (PSDs) evaluated from the BJH model based on desorption data for pure MCF-14.5 support and covered by the LYS molecules. Inset is the pore size distributions for pure MCF-6.4, MCF-30.1 supports, and after LYS adsorption. Figure S3. Influence of hydraulic pore diameter $\left(D_{h}\right)$ and surface area $\left(S_{B E T}\right)$ on the point of zero charge $\left(\mathrm{pH}_{\mathrm{pzc}}\right)$ of MCF materials after LYS adsorption. Inset: variations $\mathrm{pH}_{\mathrm{pzc}}$ as a function of $D_{h}$ and $S_{B E T}$ for pure supports. Table S1. Relative standard deviations SD(c)/co for m-exp, FOE, SOE, MOE, f-FOE, f-SOE, F-MOE, McKay pore diffusion (PDM) and IDM model (Crank). Table S2. Preparation conditions in MCF synthesis.

Author Contributions: Conceptualization, A.C., A.D.-M.; methodology, A.C.; investigation, A.C.; formal analysis, A.C., formal analysis (kinetic models), M.W.; visualization, A.C.; writing-original draft preparation, A.C.; writing-reviewing \& editing, A.D.-M., A.C.; funding acquisition, A.D.-M. All authors have read and agreed to the published version of the manuscript.

Funding: The research leading to these results has received funding from the People Programme (Marie Curie Actions) of the European Union's Seventh Framework Programme FP7/2007-2013/under REA grant agreement $\mathrm{N}^{\circ}$ PIRSES-GA-2013-612484.

Conflicts of Interest: There are no conflicts of interest to declare. 


\section{References}

1. Kirkland, J.J.; Truszkowski, F.A.; Ricker, R.D. Atypical silica-based column packings for high-performance liquid chromatography. J. Chromatogr. A 2002, 965, 25. [CrossRef]

2. Giacomelli, C.E.; Norde, W. The adsorption-desorption cycle. Reversibility of the BSA-Silica System. J. Colloid Interface Sci. 2001, 233, 234-240. [CrossRef] [PubMed]

3. Steri, D.; Monduzzi, M.; Salis, A. Ionic strength affects lysozyme adsorption and release from SBA-15 mesoporous silica. Microporous Mesoporous Mater. 2013, 170, 164-172. [CrossRef]

4. Kubiak-Ossowska, K.; Cwieka, M.; Kaczynska, A.; Jachimska, B.; Mulheran, P.A. Lysozyme adsorption at a silica surface using simulation and experiment: Effects of $\mathrm{pH}$ on protein layer structure. Phys. Chem. Chem. Phys. 2015, 17, 24070. [CrossRef] [PubMed]

5. van den Heuvel, D.B.; Stawski, T.M.; Tobler, D.J.; Wirth, R.; Peacock, C.L.; Benning, L.G. Formation of Silica-Lysozyme Composites Through Co-Precipitation and Adsorption. Front. Mater. 2018, 5, 19. [CrossRef]

6. Gustafsson, H.; Johansson, E.M.; Barrabino, A.; Odén, M.; Holmberg, K. Immobilization of lipase from Mucor miehei and Rhizopus oryzae into mesoporous silica-the effect of varied particle size and morphology. Colloids Surf. B 2012, 100, 22-30. [CrossRef]

7. Moerz, S.T.; Huber, P. Protein Adsorption into Mesopores: A Combination of Electrostatic Interaction, Counterion Release, and van der Waals Forces. Langmuir 2014, 30, 2729-2737. [CrossRef]

8. Vinu, A.; Murugesan, V.; Tangermann, O.; Hartmann, M. Adsorption of Cytochrome c on Mesoporous Molecular Sieves: Influence of $\mathrm{pH}$, Pore Diameter, and Aluminum Incorporation. Chem. Mater. 2004, 16, 3056-3065. [CrossRef]

9. Diao, X.; Wang, Y.; Zhao, J.; Zhu, S. Effect of pore-size of mesoporous SBA-15 on adsorption of bovine serum albumin and lysozyme protein. Chin. J. Chem. Eng. 2010, 18, 493-499. [CrossRef]

10. Lin, C.Y.; Yang, C.M.; Lindén, M. Influence of serum concentration and surface functionalization on the protein adsorption to mesoporous silica nanoparticles. RSC Adv. 2019, 9, 33912-33921. [CrossRef]

11. Ran, R.; You, L.; Di, B.; Hao, W.; Su, M.; Yan, F.; Huang, L. A novel chiral mesoporous binaphthyl-silicas: Preparation, characterization, and application in HPLC. J. Sep. Sci. 2012, 35, 1854-1862. [CrossRef] [PubMed]

12. Katiyar, A.; Yadav, S.; Smirniotis, P.G.; Pinto, N.G. Synthesis of ordered large pore SBA-15 spherical particles for adsorption of biomolecules. J. Chromatogr. A 2006, 1122, 13-20. [CrossRef] [PubMed]

13. Nguyen, T.P.B.; Lee, J.W.; Shim, W.G.; Moon, H. Synthesis of functionalized SBA-15 with ordered large pore size and its adsorption properties of BSA. Microporous Mesoporous Mater. 2008, 110, 560-569. [CrossRef]

14. Chen, S.; Shaoai, S.; Xiaoqiong, Z.; Qiang, H.; Liu, J.; Mingyu, D. Synthesis of large-pore mesostructured cellular foam silica spheres for the adsorption of biomolecules. J. Sep. Sci. 2014, 37, 2411-2417. [CrossRef] [PubMed]

15. Zhifang, M.; Jing, B.; Yichen, W.; Xiue, J. Impact of Shape and Pore Size of Mesoporous Silica Nanoparticles on Serum Protein Adsorption and RBCs Hemolysis. Acs Appl. Mater. Interfaces 2014, 6, 2431-2438.

16. Galarneau, A.; Mureseanu, M.; Atger, S.; Renard, G.; Fajula, F. Immobilization of lipase on silicas. Relevance of textural and interfacial properties on activity and selectivity. New J. Chem. 2006, 30, 562. [CrossRef]

17. Cai, C.; Gao, Y.; Liu, Y.; Zhong, N.; Liu., N. Immobilization of Candida antarctica lipase B onto SBA-15 and their application in glycerolysis for diacylglycerols synthesis. Food Chem. 2016, 212, 205-212. [CrossRef]

18. Zhong, N.; Chen, W.; Liu, L.; Chen, H. Immobilization of Rhizomucor miehei lipase onto the organic functionalized SBA-15: Their enzymatic properties and glycerolysis efficiencies for diacylglycerols production. Food Chem. 2019, 274, 739-746. [CrossRef]

19. Miyahara, M.; Vinu, A.; Ariga, K. Adsorption myoglobin over mesoporous silica molecular sieves: Pore size effect and pore-filling model. Mater. Sci. Eng. C 2007, 27, 232-236. [CrossRef]

20. Li, J.; Xiong, Z.; Zhou, L.; Han, X.; Liu, H. Effects of pore structure of mesoporous silicas on the electrochemical propertiesof hemoglobin. Microporous Mesoporous Mater. 2010, 130, 333-337. [CrossRef]

21. Vinu, A.; Hartmann, M. Adsorption of cytochrome c on MCM-41 and SBA-15: Influence of pH. Stud. Surf. Sci. Catal. 2004, 154, 2987-2994.

22. Meissner, J.; Prause, A.; diTommaso, C.; Bharti, B.; Findenegg, G.H. Protein Immobilization in Surface-Functionalized SBA-15: Predicting the Uptake Capacity from the Pore Structure. J. Phys. Chem. C 2015, 119, 2438-2446. [CrossRef] 
23. Pegah, S.N.Z.; Akerman, B. Immobilization of Enzymes in Mesoporous Silica Particles: Protein Concentration and Rotational Mobility in the Pores. J. Phys. Chem. B 2017, 121, 2575-2583.

24. Katiyar, A.; Ji, L.; Smirniotis, P.G.; Pinto, N.G. Adsorption of bovine serum albumin and lysozyme on silicious MCM-41. Microporous Mesoporous Mater. 2005, 80, 311-320. [CrossRef]

25. Atyaksheva, L.F.; Kasyanov, I.A.; Ivanova, I.I. Adsorptive Immobilization of Proteins on Mesoporous Molecular Sieves and Zeolites. Pet. Chem. 2019, 59, 327-337. [CrossRef]

26. Hudson, S.; Cooney, J.; Magner, E. Proteins in Mesoporous Silicates. Angew. Chem. Int. Ed. 2008, 47, 8582-8594. [CrossRef]

27. Russo, P.A.; Ribeiro Carrott, M.M.L.; Mourao, P.A.M.; Carrott, P.J.M. Tailoring the surface chemistry of mesocellular foams for protein adsorption. Colloids Surf. A 2011, 386, 25-35. [CrossRef]

28. Essa, H.; Magner, E.; Cooney, J.; Hodnett, B. Influence of $\mathrm{pH}$ and ionic strength on the adsorption, leaching and activity of myoglobin immobilized onto ordered mesoporous silicates. J. Mol. Catal. B 2007, 49, 61. [CrossRef]

29. Han, Y.; Watson, J.T.; Stucky, G.D.; Butler, A. Catalytic activity of mesoporous silicate-immobilized chloroperoxidase. J. Mol. Catal. B 2002, 17, 1. [CrossRef]

30. Deryło-Marczewska, A.; Chrzanowska, A.; Marczewski, A.W. Morphological, structural and physicochemical characteristics of MCF surface with the adsorbed OVA and BSA proteins. Microporous Mesoporous Mater. 2020, 293, 109769. [CrossRef]

31. Sing, K.S.W. Adsorption methods for the characterization of porous materials. Adv. Colloid Interface Sci. 1998, 76-77, 3-11. [CrossRef]

32. Schmidt-Winkel, P.; Lukens Jr., W.W.; Yang, P.; Margolese, D.I.; Lettow, J.S.; Ying, J.Y. Microemulsion Templating of Siliceous Mesostructured Cellular Foams with Well-Defined Ultralarge Mesopores. Chem. Mater. 2000, 12, 686-696. [CrossRef]

33. Santos, S.M.L.; Cecilia, J.A.; Vilarrasa-García, E.; Junior, I.J.S.; Rodríguez-Castell, E.; Azevedo, D.C.S. The effect of structure modifying agents in the SBA-15 for its application in the biomolecules adsorption. Microporous Mesoporous Mater. 2016, 232, 53-64. [CrossRef]

34. Vinu, A.; Murugesan, V.; Hartmann, M. Adsorption of Lysozyme over Mesoporous Molecular Sieves MCM-41 and SBA-15: Influence of $\mathrm{pH}$ and Aluminum Incorporation. J. Phys. Chem. B 2004, 108, 7323-7330. [CrossRef]

35. Moerz, S.T.; Huber, P. pH-Dependent Selective Protein Adsorption into Mesoporous Silica. J. Phys. Chem. C 2015, 119, 27072-27079. [CrossRef]

36. Puziy, A.M.; Poddubnaya, O.I.; Deryło Marczewska, A.; Marczewski, A.W.; Blachnio, M.; Tsyba, M.M.; Sapsay, V.I.; Klymchuk, D.O. Protein Adsorption by Nanostructured Carbons with Different Pore Sizes. Adsorption 2016, 22, 541-552. [CrossRef]

37. David, A.E.; Wang, N.S.; Yang, V.C.; Yang, A.J. Chemically surface modified gel (CSMG): An excellent enzyme-immobilization matrix for industrial processes. J. Biotechnol. 2006, 125, 395-407. [CrossRef]

38. Moelans, D.; Cool, P.; Baeyens, J.; Vansant, E.F. Using mesoporous silica materials to immobilise biocatalysis-enzymes. Catal. Commun. 2005, 6, 307-311. [CrossRef]

39. Wisniewska, M.; Szewczuk-Karpisz, K.; Sternik, D. Adsorption and thermal properties of the bovine serum albumin-silicon dioxide system. J. Therm. Anal. Calorim. 2015, 120, 1355-1364. [CrossRef]

40. Chrzanowska, A.; Derylo-Marczewska, A. Mesoporous silica/protein biocomposites: Surface, topography, thermal properties. Int. J. Biol. Macromol. 2019, 139, 531-542. [CrossRef]

41. Chrzanowska, A.; Derylo-Marczewska, A.; Borowski, P. Comprehensive characterization of biocomposite surface based on the mesoporous silica and lysozyme molecules: Chemistry, morphology, topography, texture and micro-nanostructure. Appl. Surf. Sci. 2020, 525, 146512. [CrossRef]

42. Sheng, L.; Wang, J.; Huang, M.; Xu, Q.; Ma, M. The changes of secondary structures and properties of lysozyme along with the egg storage. Int. J. Biol. Macromol. 2016, 92, 600-606. [CrossRef] [PubMed]

43. Khan, J.M.; Chaturvedi, S.K.; Rahman, S.K.; Ishtikhar, M.; Qadeer, A.; Ahmad, E.; Khan, R.H. Protonation favors aggregation of lysozyme with SDS. Soft Matter. 2014, 10, 2591-2599. [CrossRef] [PubMed]

44. Meissner, J.; Prause, A.; Bhuvnesh, B.; Findenegg, G.H. Characterization of protein adsorption onto silica nanoparticles: Influence of $\mathrm{pH}$ and ionic strength. Colloid Polym. Sci. 2015, 293, 3381-3391. [CrossRef]

45. Perez, D.E.L.; Aradilla, D.; Del Valle, L.J.; Aleman, C. Capacitive composites made of conducting polymer and lysozyme: Toward the biocondenser. J. Phys. Chem. C 2013, 117, 6607-6619. [CrossRef] 
46. Fang, Y.; Yi, L.; Fang, Y. Unfolding of lysozyme induced by urea and guanidine hydrochloride studied by "Phase Diagram" method of fluorescence. Acta Chim. Sin. 2003, 61, 803-807.

47. Buijs, J.; Hlady, V. Adsorption Kinetics, Conformation, and Mobility of the Growth Hormone and Lysozyme on Solid Surfaces, Studied with TIRF. J. Colloid Interface Sci. 1997, 190, 171-181. [CrossRef]

48. Shanmugaraj, K.; Umadevi, P.; Senthilkumar, L.; Ilanchelian, M. Elucidation of Binding Mechanism of Photodynamic Therapeutic Agent Toluidine Blue O with Chicken Egg White Lysozyme by Spectroscopic and Molecular Dynamics Studies. Photochem. Photobiol. 2017, 93, 1043-1056. [CrossRef]

49. Zhao, D.; Feng, J.; Huo, Q. Triblock Copolymer Syntheses of Mesoporous Silica with Periodic 50 to 300 Angstrom Pores. Science 1998, 279, 548-552. [CrossRef]

50. Doadrio, A.L.; Sousa, E.M.B.; Doadrio, J.C.; Pérez-Pariente, J.; Izquierdo-Barba, I.; Vallet-Regǔi, M. Mesoporous SBA-15 HPLC evaluation for controlled gentamicin drug delivery. J. Control. Release 2004, 97, 125-132. [CrossRef]

51. Derylo-Marczewska, A.; Marczewski, A.W.; Skrzypek, I.; Pikus, S.; Kozak, M. The effect of aging temperature on structure characteristics of ordered mesoporous silicas. Appl. Surf. Sci. 2005, 252, 625-632. [CrossRef]

52. Derylo-Marczewska, A.; Marczewski, A.W.; Skrzypek, I.; Pikus, S. Effect of Block Copolymer Type on Formation of Mesoporous Silica Structure. Pol. J. Chem. 2008, 82, 205-212.

53. Marczewski, A.W. Application of mixed order rate equations to adsorption of methylene blue on mesoporous carbons. Appl. Surf. Sci. 2010, 256, 5145-5152. [CrossRef]

54. Jaroniec, M.; Madey, R. Physical Adsorption on Heterogeneous Solids; Elsevier: Amsterdam, The Netherlands, 1988.

55. Brandt, A.; Bülow, M.; Derylo-Marczewska, A.; Goworek, J.; Schmeißer, J.; Schöps, W.; Unger, B. Novel zeolite composites and consequences for rapid sorption processes. Adsorption 2007, 13, 267-279. [CrossRef]

56. Marczewski, A.W. Analysis of kinetic Langmuir model. Part I: Integrated kinetic Langmuir equation (IKL): A new complete analytical solution of the Langmuir rate equation. Langmuir 2010, 26, 15229-15238. [CrossRef]

57. Deryło-Marczewska, A.; Marczewski, A.W. Non-homogeneity Effects in Adsorption from Gas and Liquid Phases on Activated Carbons. Langmuir 1999, 15, 3981-3986. [CrossRef]

58. De Boer, J.H.; Linsen, B.G.; Osinga, T.J. Studies on pore systems in catalysts: VI. The universal t curve. J. Catal. 1965, 4, 643-648. [CrossRef]

59. Barrett, E.P.; Joyn, L.G.; Halenda, P.P. The determination of pore volume and area distributions in porous substances. I. Computations from nitrogen isotherms. J. Am. Chem. Soc. 1951, 73, 373-380. [CrossRef]

60. Kao, C.K.; Lin, T.S.; Mou, C.Y. Enhanced Activity and Stability of Lysozyme by Immobilization in the Matching Nanochannels of Mesoporous Silica Nanoparticles. J. Phys. Chem. C 2014, 118, 6734-6743. [CrossRef]

(C) 2020 by the authors. Licensee MDPI, Basel, Switzerland. This article is an open access article distributed under the terms and conditions of the Creative Commons Attribution (CC BY) license (http://creativecommons.org/licenses/by/4.0/). 